\title{
THE FREEDOM TO FILM PORNOGRAPHY
}

\author{
Marc J. Randazza*
}

TABLE OF CONTENTS

INTRODUCTION - WHY ISN'T PORN “PROSTITUTION?" CAN YOU ONLY FILM PORN IN CALIFORNIA AND NEW HAMPSHIRE? .............................. 98

I. THE PORN INDUSTRY FALLS OUT OF LOVE WITH SOUTHERN

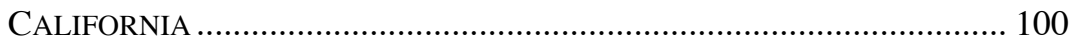

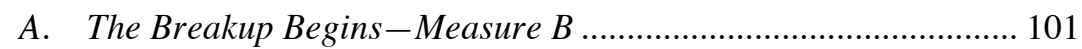

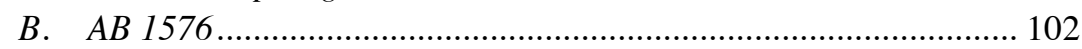

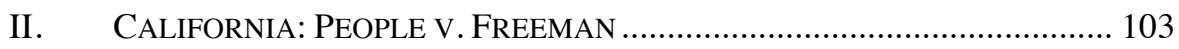

A. Freeman's Historical Context ................................................... 103

B. Freeman at the California Court of Appeals................................ 104

C. Freeman at the California Supreme Court.................................. 106

1. Freeman-Statutory Construction: "Sexual Gratification" .. 107

2. Judge McClosky's Revenge-First Amendment Protection

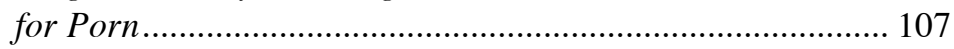

3. Censors' Last Gasp-Appeal to the Supreme Court, and Justice O'Connor's Denial .................................................... 109

III. LIVE FREE OR DIE-NEW HAMPSHIRE ……....................................... 110

IV. OUTSIDE CALIFORNIA AND NEW HAMPSHIRE ...................................... 113

A. Nevada-Legislative History Adopts Freeman ........................... 113

B. New York-Fugghedaboudit-You Can Make It Here ................. 116

1. People v. Kovner-Porn is Prostitution .................................. 116

2. New York Post-Kovner-People v. Paulino............................. 118

C. Arizona-Live Sex Shows are a "No-No", but Freeman is a

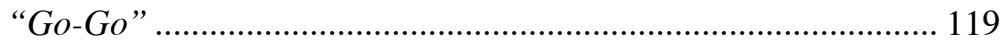

1. Statutorily, Porn is Probably Prostitution in Arizona ............ 120

2. Constitutionally, Arizona is Probably Safe for Adult Film .... 121

D. Oregon: Anything Goes-Even Live Sex Shows ......................... 123

E. Florida-Sunny or Dark? ......................................................... 127

* The author is the national president of the First Amendment Lawyers' Association, licensed to practice law in five states, and was formerly a law professor. He also used to be a commercial fisherman in Alaska, and has made more than one hundred free fall skydives (with only one of them landing him in the hospital). He is an ordained minister in the Church of the Latter Day Dude, but finds it a struggle to take 'er easy. Nevertheless, Randazza abides. 
2. Outside Polk …………………........................................... 129

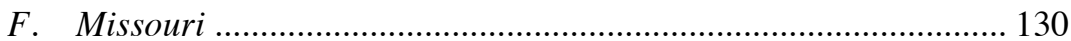

1. Show Me Prostitution .......................................................... 130

2. Porn Up Against Wahl....................................................... 131

V. THE FIRST AMENDMENT AND THE HYPOTHETICAL

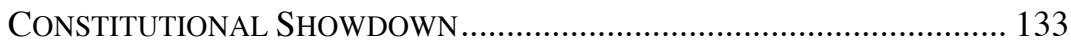

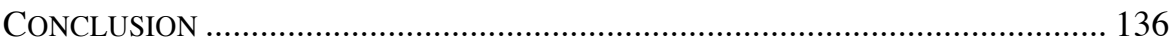

\section{INTRODUCTION - WHY ISN'T PORN “PROSTITUTION?” CAN YOU ONLY FILM PORN IN CALIFORNIA AND NEW HAMPSHIRE?}

Lawyers cringe when they hear, "You're a lawyer? I bet you didn't know ..." or, "I heard that ...." Often, these introductions are followed by some legal analysis that the half-drunken-idiot friend of your wife's collegeroommate's cousin got from his friend who saw it on "The Internet." In fact, millions of people a year mistake a sentence they read in the comments section of a random website for solid legal advice.

For example, any lawyer who practices copyright law has been "informed" that if you mail a work to yourself, the postmark on the unopened letter substitutes for a federal copyright registration. ${ }^{1}$ Similarly, criminal lawyers would all love to smack the next imbecile upside the head who "informs" them that an undercover police officer has to reveal his status if asked. ${ }^{2}$ The author himself nearly had to be hospitalized because he tried rolling his eyes to a degree of medical impossibility after having "fair use" explained to him by someone who read a thread about it on Reddit ${ }^{3}$ which, apparently in some circles, substitutes for three years of law school and a bar exam.

${ }^{1}$ The question about the "poor man's copyright" is common: "Can't I just put it in an envelope and mail it to myself?" Though this may provide some evidence in a copyright suit over who created a work and when, it is not definitive. See William Bee Ravenel Lewis, The Next Big Hit: Protecting and Exploiting (In a Good Way) Your Musician-Client's Intellectual Property, S.C. LAW., July 2014, at 47, 48. Under U.S. law, a copyright does not have to be registered; it is automatic when a work is "fixed in any tangible medium." 17 U.S.C. § 102 (2012). Understandably the poor man's copyright is not reliable since an envelope can be mailed unsealed, or steamed, or frozen open and resealed. Plus, one can register a copyright for as low as $\$ 35$ so, for many, actually registering a copyright is a poor man's copyright. See Fees, U.S. COPYRIGHT OFFICE, http://www.copyright.gov/docs/fees.html [https://perma.c c/V3PE-G7CF] (last visited Sept. 22, 2016).

${ }^{2}$ This myth likely comes from a misconception about entrapment. Entrapment occurs where a government official induces someone to commit a crime he would not have otherwise committed. See, e.g., ARIZ. REv. STAT. AnN. § 13-206 (2010). There are no laws that prevent police officers from lying about their occupation, even and especially when working undercover. Officers are even specifically immune from certain crimes when dealing drugs in an official capacity. 21 U.S.C. $\$ 885(d)$ (2012).

${ }^{3}$ Reddit is a widely popular and well-known Internet forum concerning a tremendous host of subjects. See Nancy Leong \& Joanne Morando, Communication in Cyberspace, 94 N.C. 
But, of all the legal tropes that lawyers hear shouted over the din of a somewhat crowded bar smelling of last night's spilled beer and roach spray, nothing annoys this author more than the oft-repeated, but never true, "it is legal to film porn only in California and New Hampshire." This is, at best, an uneducated fool repeating a myth. At worst, it is a lie-and a convenient one that politicians, journalists, and assorted fools continue to repeat. ${ }^{4}$ Therefore, this article is primarily aimed at the curious, but it is also intended to educate the misinformed and to embarrass those who knowingly misrepresent the state of the law.

But, if I am going to be that bold, I had better be able to answer some questions. For example, why isn't commercial porn production actually "filmed prostitution?" A simplistic view of the commercial pornography industry might suggest an easy, and contrary, answer.

$A$ : Prostitution is paying for sex.

$B$ : Commercial pornography actors take money to have sex.

$A+B=$ commercial porn actors are prostitutes, and commercial porn directors are pimps.

L. REV. 105, 146 (2015) ("Reddit is a website that bills itself as 'the front page of the Internet.' It is divided into a large number of forums, all of which are publicly accessible and in any of which anyone can write a post of any length. The site constantly updates itself, making certain content more or less visible depending on the number of views the content has received and the time since the posting. All posts are publicly available until the post is removed by their creators."); see also Ian Herbert, Where We Are with Location Tracking: A Look at the Current Technology and the Implications on Fourth Amendment Jurisprudence, 16 BERKELEY J. CRIM. L. 442, 461 n.97 (2011) ("Reddit is a website where users post content, such as links to articles or videos, and other users rate the quality of the post and post comments. The posting, comments and voting are done through anonymous usernames."). It is well established that Reddit is not a reliable source for legal advice. See, e.g., Caley Clinton, Pro Tip: Don't Ask Reddit for Legal Advice, Wis. L.J. (Aug. 11, 2014, 3:20 PM), http://wislawjournal.com/2014/08/11/pro-tip-dont-ask-reddit-for-legal-advice [https://perm a.cc/Q53E-FT3L] (comparing legal advice on Reddit to "ask[ing] the first five people you see on the street"); Samer Kalaf, This Is What Happens When You Ask Reddit for Legal Advice, Deadspin: The Concourse (Aug. 11, 2014, 12:47 PM), http://theconcourse.dead spin.com/this-is-what-happens-when-you-ask-reddit-for-legal-advi-1619404235 [https://per ma.cc/H6RN-96J9] (noting culture of unreliability and citing example of legal complications arising from Reddit user's reliance on advice parroting television plot).

${ }^{4}$ See, e.g., Jonathan Gonzalez \& John Cádiz Klemack, Porn Industry May Leave LA After New Condom Law, NBCLosAngeles.COM (Mar. 9, 2012, 6:04 PM), http://www.nbclosan geles.com/news/local/New-Condom-Law-Has-Porn-Industry-Thinking-of-New-Locations142147623.html [https://perma.cc/GXK5-22V6] (quoting municipal government official claiming it is illegal to film pornography in Arizona); Melanie Mason, California Assembly Passes Bill to Require Condom Use in Adult Films, L.A. Times (May 27, 2014), http://www.latimes.com/local/political/la-me-pc-condoms-adult-films-20140527-stor y.html [https://perma.cc/MS3L-L9KS] (noting that California State Assemblyman Isadore Hall III "said California and New Hampshire are the only two states that allow adult film production ...."). 
The California Supreme Court, though, explicitly held that porn is not prostitution. ${ }^{5}$ Likewise, a more recent New Hampshire case says the same. ${ }^{6}$ The uninformed then conclude that the other forty eight states, the District of Columbia, Guam, The Virgin Islands, American Samoa, Puerto Rico, and The Northern Marianas Islands are all unified in their resolve that a commercial film production is prostitution.

Given how simple it is, this reasoning has some appeal. But simplicity and the law seldom go well together. The real question is a two-parter. First, we must ask whether commercial pornography fits the definition of "prostitution" under state law. If it does, we must then ask whether the state's free speech clause, or the First Amendment would tolerate prosecution of a commercial pornographer under that law.

This article will clarify both questions. First, is porn actually "prostitution?" Second, can you film porn outside of California and New Hampshire? One analysis answers both questions - pornography does not fit the definition of prostitution and, even if it did, it could not be constitutionally prohibited as such. One sees how this error could be made, but only by the least-informed, and those who have some motivation to misstate the law. So, let's get started with a little bit of recent history, and then get to the analysis.

\section{THE PORN INDUSTRY FALLS OUT OF LOVE WITH SOUTHERN CALIFORNIA}

This issue of where porn can legally be filmed is currently a much debated question, given the well-publicized "condom wars" in California. Southern California, particularly the San Fernando Valley, is popularly known as the epicenter of the adult film production industry. ${ }^{7}$ Southern California once provided a socially liberal attitude, a critical mass of talent, and a California Supreme Court case explicitly protecting the industry. ${ }^{8}$ With these resources in place, porn and Southern California enjoyed a long, happy, and prosperous marriage.

In 2012, the relationship soured. First, Los Angeles County passed new regulations on porn production. ${ }^{9}$ As the industry began to eye short distance moves to other counties, ${ }^{10}$ a similar statewide bill gained traction in the Cali-

\footnotetext{
${ }^{5}$ People v. Freeman, 758 P.2d 1128 (Cal. 1988).

${ }^{6}$ State v. Theriault, 960 A.2d 687 (N.H. 2008).

${ }^{7}$ See, e.g., Clay Calvert \& Robert Richards, Law \& Economics of the Adult Entertainment Industry Today: An Inside View from the Industry's Leading Trade Publisher, 4 U. DENV. SPORTS \& EnT. L.J. 2, 2 (2008); Sue Chan, San Fernando's Open Secret, CBS News (Nov. 25, 2002, 3:27 PM), http://www.cbsnews.com/news/san-fernandos-open-secret [https://perm a.cc/2KJ2-9952].

${ }^{8}$ Freeman, 758 P.2d at 1128 .

${ }^{9}$ L.A., CAL., CODE tit. 11, div. 1, ch. 11.39 (2012).

${ }^{10}$ See, e.g., Porn Producers Consider Moving Operations from Valley to Camarillo, CBS L.A. (Mar. 28, 2013, 11:57 PM), http://losangeles.cbslocal.com/2013/03/28/porn-producersconsider-moving-operations-from-valley-to-camarillo [https://perma.cc/6RSS-3WHK].
} 
fornia state legislature. Between these regulations and a less than businessfriendly environment in California, many adult film companies in the state began calling the moving vans. ${ }^{11}$

When they did, debate raged as to whether they could leave at all. Some asked whether the porn industry was stuck in a toxic relationship with California, with its only other refuge in the far northeast. Others asked the perennial question: "Why isn't porn considered prostitution?" This article will resolve both questions.

\section{A. The Breakup Begins-Measure B}

In January 2012, Los Angeles County passed "Measure B," mandating the use of condoms in adult-film productions. ${ }^{12}$ While some might consider such a move to be "common sense," adult film professionals told another story. Producers said that condoms hurt sales. ${ }^{13}$ Simplistic thinking would suggest that porn actresses would welcome the measure, but in reality, most were against it. $^{14}$

${ }^{11}$ Richard Verrier, Porn Production Plummets in Los Angeles, L.A. TimES (Aug. 6, 2014, 5:30 AM), http://www.latimes.com/entertainment/envelope/cotown/la-et-ct-onlocation-laporn-industry-20140806-story.html [https://perma.cc/A8XB-FZN6]; Elex Michaelson, LA's 'Runaway Porn' Problem Mounting, ABC7 (Aug. 5, 2014), http://abc7.com/news/lasrunaway-porn-problem-mounting/243823 [https://perma.cc/X5J7-W4WJ]; Marc J. Randazza, Randazza Legal Group: The Case for Relocating Porn Production to Las Vegas, XBIZ (Aug. 6, 2012, 12:00 PM), http://www.xbiz.com/news/152228 [https://perma.cc/BF6LNN69]; Hunter Stuart, Los Angeles Sees Sharp Falloff in Porn Production Permit Requests, HufFington Post (Apr. 15, 2013, 6:44 PM), http://www.huffingtonpost.com/2013/04/15/ porn-los-angeles-permit-requests_n_3086479.html [https://perma.cc/PLU3-5QXM]; Lawrence G. Walters, The Sunshine State: A Ray of Hope for Adult Content Producers, WoOdhull FreEdom Found. (Mar. 19, 2012), http://www.woodhullfoundation.org/2012/ sex-and-the-law/the-sunshine-state-a-ray-of-hope-for-adult-content-producers/\#_ftn19 [https://perma.cc/DW32-V9X3].

${ }^{12}$ L.A., CAL., CODE tit. 11, div. 1, ch. 11.39 .110 (2012).

${ }^{13}$ Eyder Peralta, Los Angeles Approves Condom Requirement in Porn Shoots, NPR: THE Two WaY (Jan. 17, 2012, 10:39 AM), http://www.npr.org/sections/thetwoway/2012/01/17/145345888/los-angeles-set-to-approve-condom-requirement-in-porn-shoots [https://perma.cc/EC6P-FUQD].

${ }^{14}$ The author's experience as an attorney in the adult entertainment industry informs this view; see also Richard Abowitz, The Porn World Says No to Condoms, DaILY BEAST (Jan. 20, 2012, 10:39 AM), http://www .thedailybeast.com/articles/2012/01/20/the-porn-worldsays-no-to-condoms.html [https://perma.cc/37DJ-K3BR]. Actress Kayden Kross, said:

We have the choice already to use condoms and most don't. The reason why is that it is painful. Normal sex lasts about 15 minutes and it is slower and it is done in more natural positions. We do sex for 45 plus minutes, faster, and in more hardcore positions while opening up for the camera. That kind of friction with a condom is very painful. As a performer, I used a condom twice and never again.

Id.; see also Jason Shachner, Unwrapped: How the Los Angeles County Safer Sex in the Adult Film Industry Act's Condom Mandate Hurts Performers \& Violates the First Amendment, 24 Health Matrix 345, 346 (2014); Chauntelle Anne Tibbals "[A]nything That 
The measure went further than just requiring condoms, though. Measure B required adult film producers to obtain a permit before shooting "any film, video, multimedia or other representation of sexual intercourse."15 It further allowed Los Angeles County to conduct warrantless searches and to revoke permits with largely unbridled discretion. ${ }^{16}$ These provisions were deemed unconstitutional and were enjoined by the Central District of California. ${ }^{17}$ Despite that ruling, the regulation requiring the mandatory use of condoms on set remained intact over a challenge by the adult film industry. ${ }^{18}$

\section{B. $A B 1576$}

Assembly Bill 1576 was a proposed California state law based on the Los Angeles condom ordinance. When it came to the California State Assembly, opponents claimed that the multi-billion dollar industry would leave California. ${ }^{19}$ Regulation proponents, however, argued that the industry could not leave because it was the only state in the Union, aside from New Hampshire, where porn production is legal. ${ }^{20}$ Those supporters believed the porn industry was trapped in California, and thus, the state's legislature and regulators could treat the industry any way they liked, with no fear of porn's jobs and billions of dollars in revenue going elsewhere. ${ }^{21}$

Forces Itself into My Vagina Is by Definition Raping Me ..."-Adult Film Performers and Occupational Safety and Health, 23 STAN. L. \& POL'Y REV. 231, 232 (2012).

${ }^{15}$ L.A., CAL., CODE tit. 11, div. 1, ch. 11.39 .010 (2012).

${ }^{16}$ Id. chs. 11.39.110, 11.39.130; Vivid Entm't, LLC v. Fielding, 774 F.3d 566, 571 (9th Cir. 2014).

17 Vivid Entm't, LLC v. Fielding, 965 F.Supp.2d 1113, 1134 (C.D. Cal. 2013).

${ }^{18}$ Id., aff'd, 774 F.3d 566 (9th. Cir. 2014). For a discussion of the constitutional implications of the remaining portion of the ordinance, see Elizabeth Sbardellati, Skin Flicks Without the Skin: Why Government Mandated Condom Use in Adult Films Is a Violation of the First Amendment, 9 Nw. J.L. \& SoC. POL'Y 138 (2013); Shachner, supra note 14. In fact, even HIV/AIDS prevention organizations opposed the ordinance for violating standing health codes and personal privacy. Eric Paul Leue, Prominent HIV/AIDS Organizations Oppose California's A.B. 1576, HufFington Post (Aug. 12, 2014, 7:41 PM), http://www.huffingtonpost.com/eric-paul-leue/prominent-hivaids-organiz_b_5663504.html [https://perma.cc/ZRX6-VJDM].

${ }^{19}$ Hearing on A. B. 1576 Before the Assemb. Comm. on Arts, Entm't, Sports, Tourism, \& Internet Media, 2014 Leg., 2013-2014 Sess. 7 (Cal. 2014), http://aart.assembly.ca.gov/sites/aart.assembly.ca.gov/files/AB\%201576\%20analysis.pdf [htt ps://perma.cc/CS2H-V8GB].

${ }_{20}^{20}$ AHF : Top Porn Lawyer Says Industry Can't Move from CA, Bus. WIRE (Sep. 24, 2012, 9:30 AM), http://www.businesswire.com/news/home/20120924005561/en/AHF-Top-PornLawyer-Industry-Move-CA [https://perma.cc/97HR-7PJ2]; The Problem with Producing Porn Outside California . . ., Adult BIz LAW (Sep. 21, 2012), http://adultbizlaw.com/theproblem-with-producing-porn-outside-california [https://perma.cc/W2A3-HDRB]; see also, Hearing on A. B. 1576, supra note 19; Mason, supra note 4.

${ }^{21}$ Mason, supra note 4. 
While $\mathrm{AB} 1576$ failed, the debate over it gave new life to the myth that California and New Hampshire were the only places in the United States where it is legal to make adult films. Journalists thought they were the first to discover this hidden legal gem. For example, Dennis Romero writing in the L.A. Weekly falsely declared: "Porn is only explicitly legal in California and New Hampshire. Otherwise it's prostitution." ${ }^{22}$ And, with that, he damaged his own credibility and made all of his readers that much less educated. To understand how, we must go back to the beginning - to the seminal California Supreme Court case, People v. Freeman.

\section{CALIFornia: PEOPle V. FreEMAN}

In the 1988 case People v. Freeman, the California Supreme Court ruled that when an adult film company pays actors to appear in a film, it is not prostitution. ${ }^{23}$ In that case, Harold Freeman, a professional porn producer and director, hired and paid actors to perform in a non-obscene erotic film called Caught from Behind, Part II. ${ }^{24}$ It did not win an Oscar that year.

\section{A. Freeman's Historical Context}

To understand that case and what comes after, it is important to delve at least a little bit into the "culture wars" that brought it about. In 1969, President Johnson formed the President's Commission on Obscenity and Pornography to study the negative effects of pornography on the public. ${ }^{25}$ Much to the dismay of social conservatives ${ }^{26}$ the Commission found no such negative effects. In fact, they found precisely the opposite: "In sum, empirical research designed to clarify the question has found no evidence to date that exposure to explicit sexual materials plays a significant role in the causation of delinquent or criminal behavior among youth or adults. The Commission cannot conclude that exposure to erotic materials is a factor in the causation of sex crime or sex delinquency.",27

${ }^{22}$ Dennis Romero, Porn Industry Appears to Admit It's Breaking the Law, LA WEEKLY (Sept. 22, 2015, 8:04 AM), http://www.laweekly.com/news/porn-industry-appears-to-admitits-breaking-the-law-6073152 [https://perma.cc/B2NN-477W].

${ }^{23}$ People v. Freeman, 758 P.2d 1128 (Cal. 1988).

${ }^{24} I d$. at 1129.

${ }^{25}$ Cong. COMmission on Obscenity and PoRnography, The RePORT OF the COMmission ON OBSCENITY AND PORNOGRAPHY (1970) [hereinafter COMMISSION REPORT], https://bab el.hathitrust.org/cgi/pt?id=umn.31951p00073248m;view=1up;seq=1 [https://perma.cc/FA4 F-S65W].

${ }^{26}$ Richard M. Nixon, Statement about the Report of the Commission on Obscenity and Pornography, 381 Pub. PAPERS 940-41 (Oct. 24, 1970).

27 COMMISSION REPORT, supra note 24, at 27 (footnote omitted). 
The Commission found that pornography was far from troubling, and even recommended repealing laws restricting pornography distribution to adults. The Commission wrote: "The Commission believes that there is no warrant for continued governmental interference with the full freedom of adults to read, obtain or view whatever such material they wish., 28

A landmark adult entertainment case shortly thereafter noted the findings: "On the positive side, explicit sexual materials are sought as a source of entertainment and information by substantial numbers of American adults. At times, these materials also appear to serve to increase and facilitate constructive communication about sexual matters within marriage." 29

In the 1980s, Ronald Reagan shepherded a new wave of social conservatism. ${ }^{30}$ The 1980 s saw a number of attempts to curb pornography, specifically in California. ${ }^{31}$ Reagan commissioned his Attorney General, Ed Meese, to come up with a new study to contradict the prior Commission's report. ${ }^{32}$ Riding this wave, a California prosecutor tried to put an end to "that kind of thing" in California by charging Harold Freeman with pandering-defined as "procur[ing] another person for the purpose of prostitution." 33 However, Freeman was not your garden-variety pimp; he was producing an adult film. ${ }^{34}$

\section{B. Freeman at the California Court of Appeals}

Freeman filmed Caught From Behind, Part II, in a private residence that was closed to the public. ${ }^{35}$ He paid the featured actors, as well as the modeling

${ }^{28} I d$. at 52 .

${ }^{29}$ Paris Adult Theatre I v. Slaton, 413 U.S. 49, 108 n.26 (1973).

30 See, e.g., Gleaves Whitney, Ronald Reagan and the Conservative Movement (2004),

http://scholarworks.gvsu.edu/cgi/viewcontent.cgi?article=1093\&context=ask_gleaves [https://perma.cc/83WB-FL3F]; Gil Troy, The Age of Reagan, GILDER LEHRMAn InST. Am. HIST., https://www .gilderlehrman.org/history-by-era/essays/age-reagan [https://perma.cc/EY 36-MA2D] (last visited Sept. 23, 2016).

${ }^{31}$ Dennis Anderson, Pornography Industry Poses Problems in California, LAWrence DAILY J.-WORLD, Jun. 1, 1986, at 7D, https://news.google.com/newspapers?nid=21 $99 \&$ dat $=19860601 \& \mathrm{id}=\mathrm{g} 0$ wyAAAAIBAJ $\&$ sjid $=$ cuUFAAAAIBAJ $\&$ pg $=6802,191955 \& \mathrm{hl}=\mathrm{e}$ n [http://perma.cc/MDE6-KB8C]; California Attacking Pornography, SUMTER DAILY ITEM, Aug. 6, 1985, at 8A, https://news.google.com/newspapers?nid=1979\&dat=19850805\&id= 1pAiAAAAIBAJ\&sjid=5q0FAAAAIBAJ\&pg=5751,5691979\&hl=en [https://perma $. c c / 553$ R-5TB5].

${ }^{32}$ U.S. Dep't of Justice, Attorney General Commission on Pornography, Final REPORT (1986), https://babel.hathitrust.org/cgi/pt?id=mdp.39015073491824;view=1up;seq= 1 [https://perma.cc/GV74-MT3C].

33 Cal. Penal Code $§ 266 i$ (West 2014).

${ }^{34}$ See generally IDIOCRACY (Twentieth Century Fox 2006) ("You see, a pimp's love is very different from that of a square.").

${ }^{35}$ People v. Freeman, 758 P.2d 1128, 1129 (Cal. 1988). 
agency that provided some of them. ${ }^{36}$ Freeman was then charged with five counts of pandering under California's Pimping Statute, Penal Code section $266 \mathrm{i}$, based on his conduct of hiring the five actresses in the film. ${ }^{37}$ A jury found him guilty, and he was sentenced to ninety days in jail, five years' probation, and a $\$ 10,000$ restitution payment. ${ }^{38}$

Freeman appealed and received a cursory affirmation of his sentence from the California Court of Appeals, rejecting all of Freeman's arguments, with neither citation nor analysis. Freeman argued that the prostitution statute did not fit his conduct because there was no "sexual gratification" inherent in the sexually explicit performances. The appellate court rejected that argument stating:

The actors and actresses herein involved were employed to engage in acts or prostitution, which is defined in numerous California cases as the engaging in sexual acts for money. The people herein engaged agreed to and did engage in sexual conduct and testified that they "acted" before the cameras in the production of the motion picture herein in question "for the money they received." The guilt of the defendant of the crime charged and of which he was convicted is clear. $^{39}$

Freeman also argued that he had a First Amendment right to produce adult films, and that his conviction violated that right. The California Appellate Court gave even shorter treatment to this argument:

Much of appellant's opening brief is devoted to a discussion of the application of the First Amendment. That discussion is out of place in this appeal. It is well settled that the distribution of a movie or book is protected by the First Amendment. However, a criminal act is not protected under the First Amendment merely because it occurs within the context of a motion picture production. ${ }^{40}$

While the majority opinion was a mere 250 words, there was a lengthy, and prescient dissent by Judge Deborah Wilson McClosky. ${ }^{41}$ In her dissent, Judge McClosky discussed the fact that merely adding the First Amendment to unlawful conduct, by filming it, would not immunize a defendant from liability. ${ }^{42}$ Even so, she relied heavily upon the weighty pronouncement by the California Supreme Court in Barrows v. Municipal Court, to pronounce her view that the creation of expressive materials required a different analysis.

The Barrows court went on to explain:

Our holding here does not suggest that acts which are independently prohibited by law may be consummated without sanction on the stage merely because they occur during the course of a theatrical play. Dramatic license would not supply

${ }^{36} I d$.

${ }^{37} I d$.

38 Id. at $1129-30$.

${ }^{39}$ People v. Freeman, 233 Cal. Rptr. 510, 511 (Cal. Dist. Ct. App. 1987), rev'd, 758 P.2d

1128 (Cal. 1988).

${ }^{40} \mathrm{Id}$. at $510-11$.

${ }^{41} I d$. at 512.

${ }^{42} I d$. 
indulgence for the actual murder of the villain, the rape of the heroine, or the maiming of the hero. Neither do we intend to imply, however, that conduct or speech in a theatrical production is to be judged by the same standards as conduct or speech occurring on the street or other public place. Giannini makes it clear that "acts which are unlawful in a different context, circumstance, or place, may be depicted or incorporated in a stage or screen presentation and come within the protection of the First Amendment, losing that protection only if found to be obscene." We particularly reaffirm this portion of the decision in Giannini, for any more restrictive rule could annihilate in a stroke much of the modern theater and cinema. The loss to culture and to First Amendment rights would be equally tragic. ${ }^{43}$

Judge McClosky admitted that Caught from Behind, Part II may be of little "value to our culture," but she was not so arrogant as to suggest that a value analysis was necessary or proper.

I cannot conclude that the purpose of the Legislature in enacting Penal Code section 266i was to prevent the production or distribution of theatrical plays or motion pictures depicting sex acts between consenting adults. Had it wished to do so the Legislature could have added the production of such plays or films to the list of proscribed acts and conduct listed in that section. It did not do so. It is not our right to interpret a criminal statute broadly to aid a finding of guilt, especially where to do so invades a First Amendment protection. It is plain to me that the defendant's purpose here was to profit from making a motion picture and not "to procure a person, or attempt to procure a person, for the purpose of prostitution" within the meaning of Penal Code section 266i. ${ }^{44}$

In what seems to be a sarcastic retort to the majority's remark that Freeman's guilt was “obvious," Judge McClosky concluded her dissent with a bit of attitude. "It is obvious that the strictures of the First Amendment may be just as effectively violated by penalizing production as by penalizing distribution or viewing., 45

\section{Freeman at the California Supreme Court}

While Judge McClosky was alone in her dissent at the Court of Appeals, her rationale was both compelling and inspiring - at least inspiring enough to convince Freeman that his cause was worth fighting for. Freeman appealed to the California Supreme Court, which roundly rejected the 250 word affirmation. The Supreme Court seemed persuaded by Judge McClosky's dissent and held that Freeman was a free man, both because his conduct did not fit the prostitution statute, and that even if it did, the First Amendment would not tolerate such a conviction. ${ }^{46}$

${ }^{43}$ Id. (McClosky, J., dissenting) (quoting Barrows v. L.A. Mun. Ct., 464 P.2d 483, 488-90 (Cal. 1970) (citations omitted)).

${ }^{44}$ Id.

${ }^{45} I d$. at 513-14.

${ }^{46}$ People v. Freeman, 758 P.2d 1128, 1131-35 (Cal. 1988). 


\section{Freeman-Statutory Construction: "Sexual Gratification"}

The California Supreme Court first tackled the issue of whether Freeman's conduct met the statutory definition of "prostitution." "In order to constitute prostitution, the money or other consideration must be paid for the purpose of sexual arousal or gratification. ${ }^{, 47}$ This is the heart of the matter-the purpose or intent. Who is gratifying whom, and more importantly, why?

Under California Law, the elements of "prostitution" include a payment and a sexual act. ${ }^{48}$ Looking at it simplistically, a porn shoot seems to qualify. After all, someone is having sex and getting paid for it. Freeman argued, in part, that since there was no "customer," there was no prostitution. ${ }^{49}$ The California Supreme Court brushed that aside in favor of an even simpler intent analysis: "Whether or not prostitution must always involve a 'customer,' it is clear that in order to constitute prostitution, the money or other consideration must be paid for the purpose of sexual arousal or gratification."

The Freeman court made a distinction between paying to obtain personal pleasure, and paying to obtain acting services. ${ }^{51}$ Under the California Supreme Court's interpretation of the California prostitution statute, the payment must be "for the purpose of sexual arousal or gratification." 52 Since the payment was for acting fees, and not to incentivize sexual gratification, it was not prostitution. $^{53}$

\section{Judge McClosky's Revenge-First Amendment Protection for Porn}

The Freeman court could have stopped there. Mr. Freeman's conduct did not fit the statute, and he lacked "the requisite mens rea or purpose to establish procurement for purposes of prostitution." 54 The end, right? Not quite.

The California Supreme Court seemed to be moved by Judge McClosky's dictum that the California legislature could have added the production of sexually explicit plays or films to the prostitution statute, if it wished to. ${ }^{55}$ The Court pre-emptively knocked out that choice by holding that even if the legislature made such a choice, it would be unconstitutional. ${ }^{56}$

${ }^{47} I d$. at 1131 (emphasis omitted).

${ }^{48} I d$. at 1130

${ }^{49}$ Id. at $1130-31$.

${ }^{50} I d$. at 1131 (emphasis omitted).

${ }^{51} I d$.

${ }^{52} I d$.

${ }^{53} I d$.

${ }^{54} I d$.

${ }^{55}$ People v. Freeman, 233 Cal. Rptr. 510, 512 (Cal. Dist. Ct. App. 1987) (McClosky, J., dissenting) ("Had it wished to do so the Legislature could have added the production of such plays or films to the list of proscribed acts and conduct listed in that section.").

${ }^{56}$ Freeman, 758 P.2d at 1131. 
Voltaire, the French Enlightenment philosopher, is credited with saying, "I disapprove of what you say, but I will defend to the death your right to say it.. ${ }^{, 77}$ The California Supreme Court presented that very attitude, a little less elegantly, but in the words necessary to give adult film production the cover of First Amendment protection. "Regardless of our view of the social utility of this particular motion picture, our analysis must begin with the premise that a nonobscene motion picture is protected by the guarantee of free expression found in the First Amendment." 58

The California Supreme Court held that even if it deemed payment for pornographic acting services to be "prostitution," the First Amendment would not tolerate a prostitution charge under those circumstances. ${ }^{59}$ To hold otherwise would mean that an entire genre of film would be per se unlawful. ${ }^{60}$ Specifically, the Court stated "the application of the pandering statute to the hiring of actors to perform in the production of a nonobscene motion picture would impinge unconstitutionally upon First Amendment values." ${ }^{61}$ In fact, if the statute were so interpreted, it would sweep up a vast swath of expression, leaving us with no more commercially produced pornography.

The California Supreme Court determined that the purpose of the prostitution statute was to address a state interest in combatting prostitution, which did not apply in this case. ${ }^{62}$ The payment was "for the right to photograph the performance" and not to induce a crime separate from the filming. ${ }^{63}$ Moreover, the Court held that a strict reading of a prostitution statutory definition "could annihilate in a stroke much of the modern theater and cinema." ${ }^{64}$ This was a preemptive shot across the legislature's bow - warning them that even if they chose to amend the statute to remove the gratification requirement, it would not be open season on adult film producers. ${ }^{65}$

The Freeman court thus gave us the alternative rationale. The First Amendment bars any prostitution charge in this setting, whether the language of the prostitution statute fits the conduct or not. From the outset of the opinion the Court remarked:

57 See Ammond v. McGahn, 390 F. Supp. 655, 661 (D.N.J. 1975). "Although this quote is commonly attributed to Voltaire, it is actually a paraphrase of his attitude by S. G. Tallentyre in Friends of Voltaire 199 (London 1907)." Id. at 661 n.3; see also Young v. Am. Mini Theatres, 427 U.S. 50, 63 n.19 (1976) (citing Tallentyre and noting that the statement is "[a] remark attributed to Voltaire" and not crediting it as an actual quote).

${ }^{58}$ Freeman, 758 P.2d at 1131.

${ }^{59} \mathrm{Id}$.

${ }^{60} I d$. at 1132.

${ }^{61} I d$. at 1131 (emphasis added).

${ }^{62} I d$. at 1132.

${ }^{63} \mathrm{Id}$. at 1134 .

${ }^{64} I d$. at 1132 (quoting Barrows v. L.A. Mun. Ct., 464 P.2d 483, 488-90 (Cal. 1970)).

${ }^{65} \mathrm{Id}$. 
The film was not determined to be obscene and for purposes of this review must be deemed to be not obscene. Thus the prosecution of defendant under the pandering statute must be viewed as a somewhat transparent attempt at an "end run" around the First Amendment and the state obscenity laws. Landmark decisions of this court and the United States Court compel us to reject such an effort. ${ }^{66}$

In an effort to save the prosecution, the state argued that there might be compelling governmental interests at play. The state argued that interpreting the statute to prohibit porn production would advance the interest of preventing profiteering from prostitution, and it would advance a public health purpose, namely the prevention of sexually transmitted diseases. ${ }^{67}$ The California Supreme Court rejected both rationales.

Punishment of a motion picture producer for the making of a nonobscene film, however, has little if anything to do with the purpose of combatting prostitution. Rather, the self-evident purpose of the prosecuting authority in bringing these charges was to prevent profiteering in pornography without the necessity of proving obscenity. The fact that the People concede that a film identical to that in this case could be made lawfully if the performers were not paid also belies the asserted "public health" interest. Both these suggested "interests" not only directly involve the suppression of free expression but are, in the context of a pandering prosecution for the making of a nonobscene motion picture, not credible. $^{68}$

Therefore, even amending the statute to remove the gratification requirement would not permit prosecution of adult film producers as pimps. As long as the acts being filmed were otherwise lawful, and there was no other independent basis for prosecution (for example, filming in public or a lack of consent), then the state had no interest in prohibiting the production of a porn film, and the First Amendment would tolerate no such interference.

\section{Censors' Last Gasp-Appeal to the Supreme Court, and Justice O'Connor's Denial}

Freeman has been influential outside California-far more than might be expected of a mere state supreme court case. This is not only because of its independent analysis, but also at least in some part, due to the state's efforts to have the decision set aside. After the order, California sought a stay of the Freeman decision from the United States Supreme Court, with Justice O’Connor as Circuit Justice. ${ }^{69}$

Justice O'Connor denied the stay, noting that even if the Supreme Court reversed the decision, upon remand, the California Supreme Court's statutory

${ }^{66} I d$. at 1130

${ }^{67} \mathrm{Id}$. at 1132

${ }^{68} I d$. at 1132-33.

${ }^{69}$ California v. Freeman, 488 U.S. 1311 (1989). 
construction position would still control the outcome. ${ }^{70}$ Nevertheless, in denying the stay, Justice O'Connor gave a hint at how she would have held on the First Amendment issue. Without explicitly holding so, she seemed to approve of the California Supreme Court's view on end-runs around the First Amendment.

Justice O'Connor pointed out the California Court's observation that the prosecution seemed ignoble:

[T] he prosecution of [Freeman] under the pandering statute must be viewed as a somewhat transparent attempt at an "end run" around the First Amendment and the state obscenity laws. Landmark decisions of this court and the United States Supreme Court compel us to reject such an effort. ${ }^{71}$

Nevertheless, she was obligated to make the decision based only on the California Supreme Court's interpretation of the California statute. The U.S. Supreme Court lacked any power to interpret a California law differently than the California Supreme Court. As Justice O'Connor wrote, "Interpretations of state law by a State's highest court are, of course, binding upon this Court." 72

Justice O'Connor's denial of the stay lacks the authority of a decision on the merits, and Justice O'Connor did not add any editorial content. Nevertheless, a positive reading seems consistent with existing decisions, and she was within her rights to criticize the California Supreme Court's First Amendment analysis, had she seen fit to do so. Given that Justice O'Connor declined to do so, and she seemed to disapprove of the prosecution, the Freeman decision has a bit more robust effect outside California's borders. It is, therefore, somewhat more powerful than a mere State Supreme Court decision-but no one should mistake Justice O'Connor's denial of the stay as binding precedent.

\section{LIVE FREE OR DIE-NEW HAMPSHIRE}

New Hampshire is not the first place that comes to mind when one thinks of the adult entertainment industry. ${ }^{73}$ Nevertheless, ever since 2008 , the industry has looked at it, at least out of the corner of its eye, as the only state with an explicit Freeman-style court decision.

\footnotetext{
${ }^{70} I d$. at 1315.

${ }^{71} I d$. at 1314 .

${ }^{72} I d$. at 1313 (citations omitted).

${ }^{73}$ New Hampshire does box above its weight class when it comes to porn production. It is the home to Wasteland Productions, one of the adult entertainment industry's first online companies, led by Colin Rowntree, a member of the Adult Video News Hall of Fame. See, e.g., Charlie Warzel, If They Build It, Will We Come? Meet the Tech Entrepreneurs Trying to Take Back the Porn Industry, BuzZFEED, (Sept. 24, 2015, 5:31 AM), http://www.buzz feed.com/charliewarzel/if-they-build-it-will-we-come-meet-the-tech-entrepreneurstr\#.arJ3bbJD0 [https://perma.cc/EQU5-M4Q4].
} 
For the twenty years following Freeman, the decision seemed to stand as an instruction to prosecutors nationwide that porn is not prostitution. ${ }^{74}$ Or at least it seems this way, because there are no reported decisions involving attempts to prosecute based on pure film production facts, and this is in light of the fact that there is porn production in all fifty states. Anecdotally, there have been threats of Freeman-style prosecutions from time to time, but none ever made their way to a reported decision, nor even a newspaper article. ${ }^{75}$

By the time the Freeman decision was almost old enough to shop at one of the Granite State's once vital state liquor stores ${ }^{76}$ a New Hampshire prosecutor decided to try out the long discredited prosecutorial strategy on the theory that Freeman was obviously not binding outside California. The result was that the New Hampshire Supreme Court affirmed Freeman's logic in State v. Theriault, and held that paying someone to act in an adult film was not the same as paying a prostitute for sex. ${ }^{77}$ But the Theriault Court went a bit further. The Court engaged in the same constitutional analysis as Freeman but relied on the New Hampshire Constitution. ${ }^{78}$ This shielded the decision from any possible federal challenge or appeal to the United States Supreme Court.

The facts of Theriault are a little less clear than those in Freeman. Robert Theriault was working as a court security officer when C.H. and J.S. came into the court to pay some fines. ${ }^{79}$ Theriault learned that the woman was "in a dire financial situation. ${ }^{\prime 80} \mathrm{He}$ then asked the couple if they "needed employment."

${ }^{74}$ In dicta, a New York court seemed to view Freeman analysis as an obvious conclusion. See People v. Paulino, No. 6687/04, 2005 N.Y. Misc. LEXIS 3430, at*14 (N.Y. Sup. Ct. Aug. 4, 2005).

${ }^{75}$ Recently, officials in some states - like Arizona discussed below - have stated that pornographers "could be" prosecuted under state prostitution laws. But even legal experts shy away from stating a legal conclusion that pornographers will be or even can be prosecuted. See infra Part IV.C. Actual threats of prosecution have been lacking since the 1980s. Randy Dotinga, Legal Threats Stalk Adult Sites, WIRED (June 15, 2004, 12:00 PM), http://www.wired.com/2004/06/legal-threats-stalk-adult-sites/ [https://perma.cc/MNH6-6U U5]; Lori Santos, Meese Says Obscenity Team Will Prosecute Pornographers, BRYAN Times, Oct. 23, 1986, at 10; Douglas Shuit \& Paul Jacobs, Law Likely to Lead to Stronger Curbs on Pornographers, L.A. TIMES (Apr. 16, 1986), http://articles.latimes.com/1986-0416/news/mn-46_1_california-law [https://perma.cc/U6EB-LXLC].

${ }^{76}$ For many years, Massachusetts prohibited the sale of alcohol on Sundays. New Hampshire's state liquor stores, conveniently located along the highways from Massachusetts, served a valuable societal service. Jenna Russell, Sunday Liquor Sale Ban to End, Boston GLOBE (Nov. 23, 2003), http://archive.boston.com/news/local/articles/2003/11/23/sun day_liquor_sale_ban_to_end/[https://perma.cc/FXT8-VT2N].

77 State v. Theriault, 960 A.2d 687, 692 (N.H. 2008).

${ }^{78}$ Id. New Hampshire looks to its state constitution before engaging in an analysis of any federal counterparts. See id. at 693.

${ }^{79}$ Id. at 688.

${ }^{80}$ State v. Theriault, 949 A.2d 678, 679 (N.H. 2008) Note this is a separate appeal in which Theriault's conviction on other charges, not including videotaping, was upheld. 
After informing them that he could not discuss the job at the courthouse, he met them in a parking lot behind a bank. The defendant asked the couple if they wanted to make "f . . flicks." The defendant specified the details: he would pay them fifty dollars per hour, he would rent a hotel room, and they would use temperature blankets and different condoms while the defendant videotaped them having intercourse. ${ }^{81}$

If that sounds shady, at least Theriault conditioned the offer on the taping taking place in a private hotel room "so [they] didn't feel uncomfortable.," The State charged him with violating the prostitution statute by offering to pay another to engage in sexual contact. ${ }^{83}$

The State Supreme Court succinctly summarized the issues as follows:

The facts boil down to the defendant offering to remunerate the couple to have sexual intercourse while being videotaped. There was no evidence or allegation that the defendant solicited this activity for the purpose of sexual arousal or gratification as opposed to making a video. The State did not charge the defendant under the "sexual contact" portion of the statute and therefore there was no finding by the trial court that the defendant acted for the purpose of sexual arousal or gratification. Thus, if the statute constitutionally prohibits the defendant's conduct, a request to pay two individuals to make a sexually explicit video would be unprotected under the free speech guarantees of the State Constitution. ${ }^{84}$

Despite Theriault's unorthodox proposal, there was no evidence that his offer was anything other than good clean American porn production. "C.H. testified that [Theriault] offered to pay fifty dollars per hour 'to make pornography.' The only evidence in this record as to [his] intent is that he intended to make pornography." 85

The Theriault court then ran over well-traveled legal ground. The Court noted that Miller v. California ${ }^{86}$ and Ashcroft v. Free Speech Coalition ${ }^{87}$ established that pornography could be banned only if it is deemed legally obscene. ${ }^{88}$ The Court recognized the Freeman straw man - that adding a camera to a crime does not make it into protected expression. ${ }^{89}$ The New Hampshire Supreme

81 Theriault, 960 A.2d at 688.

${ }^{82} \mathrm{Id}$. at 690 .

$83 I d$. at 688 .

${ }^{84} \mathrm{Id}$. at 690 .

${ }^{85}$ Id. at 692.

${ }^{86}$ Miller defines the standard for obscenity as an exception to First Amendment speech protections. Miller v. California, 413 U.S. 15, 21 (1973). A court must consider if the work appeals to the prurient interest, depicts or describes sexual conduct in an offensive manner under applicable state law, and whether, as a whole, the work lacks serious literary, artistic, political, or scientific value. Id. at 24 .

${ }^{87}$ Ashcroft v. Free Speech Coalition, 535 U.S. 234, 240 (2002). Under Ashcroft even a child pornography statute can be found overbroad and unconstitutional if it reaches protected speech. Id.

${ }^{88}$ Theriault, 960 A.2d at 690.

${ }^{89}$ Id. at 692. 
Court then burned the straw man by making the obvious finding that filming a crime does not automatically transform it into protected activity. ${ }^{90}$ The Court made it clear that creation of expressive materials is a special case. ${ }^{91}$ In other words, in the case of pornography, the actors are paid to be in the film, not for the sexual act. They are, therefore, not filming a crime of prostitution, they are just filming a sexual performance, and prohibiting this would be an unjustified infringement upon free expression. ${ }^{92}$ Accordingly, the state could not use the prostitution statute as a back door prohibition on adult film production. New Hampshire followed Freeman to its inevitable conclusion.

\section{OUTSIDE CALIFORNIA AND NEW HAMPSHIRE}

The "Billy Madisons" of the legal world already know what we have gone through thus far-California and New Hampshire have decisions that make porn production legal in those states. ${ }^{93}$ But what about other states? The fact is, there are no decisions outside California and New Hampshire that explicitly adopt Freeman, thus, leading to the myth that it is illegal to film pornography anywhere else. But, this is not the case.

For example, Nevada has a favorable legislative history in its prostitution statute that recognizes Freeman. ${ }^{94}$ Beyond Nevada, some states have decisions containing strong dicta that suggests porn production is permitted (i.e., New York ${ }^{95}$ and Arizona). ${ }^{96}$ Other states have cases involving live sex shows that either make it clear that the state would permit porn production (Oregon) ${ }^{97}$ or imply as much (Arizona). ${ }^{98}$ In others, like Missouri, the result is less certain, at least from a statutory construction perspective. ${ }^{99}$ But, ultimately, the First Amendment analysis from Freeman suggests that porn production is almost certainly protected activity in all fifty states.

\section{A. Nevada-Legislative History Adopts Freeman}

Nevada has never been a stranger to "sin-based" businesses, and it has long been home to adult film production. ${ }^{100}$ Once the adult industry began looking

90 Id.

91 Id. at 690.

${ }_{92}$ Id. at 692.

93 See Theriault, 960 A.2d. at 688; People v. Freeman, 758 P.2d 1128, 1131 (Cal. 1988); see also supra Parts II-III.

94 See infra Part IV.A.

95 See infra Part IV.B.

96 See infra Part IV.C.

${ }^{97}$ See infra Part IV.D.

98 See infra Part IV.C.

${ }^{99}$ See infra Part IV.F.

${ }^{100}$ Las Vegas' nickname of "Sin City" does not simply derive from its gambling attractions. The Author has represented companies using Las Vegas as a location for porn production 
for a new home, Las Vegas was an obvious name on the short list. Clyde DeWitt, a veteran adult industry attorney, confirmed to the Las Vegas Sun that the Las Vegas valley is a reasonable place for the porn industry to relocate. ${ }^{101}$ "Las Vegas and Clark County have both licensed adult motion picture studios, and within the last year, a major porn production company set up shop in Southern Nevada." 102 Many found that creating a greater presence in Nevada just made good business sense, even if California re-welcomed them. DeWitt said that "the economy is so much more favorable ... . They get commercial space cheaper. There's no state income tax ... Housing is literally half or less than what they pay [in California]. That's an attractive proposition."103

DeWitt is not the only prominent Las Vegan to welcome the industrylocal politicians are even receptive. Whereas politicians in most municipalities would not want (or pretend to not want) the adult entertainment industry to come to their town in the interest of being re-elected, Las Vegas politicians have reacted differently. Last year Clark County commissioner Chris Giunchigliani commented on the issue, stating that "[i]t's a legalized industry and properly regulated, so I don't see it as a problem .... I think the city and the county will benefit from any expansion of the film industry. It's economic diversification." ${ }^{104}$ In fact, Clark County even has an adult film studio accommodation in its zoning code. ${ }^{105}$ It would make little sense for the state's largest municipality to create licensing and zoning regulations for a business activity that could be deemed contrary to state law.

Of course, Nevada allows prostitution in certain counties. Therefore, the whole Freeman/Theriault analysis might seem unnecessary. Yet contrary to popular belief - and perhaps as a matter of disappointment to millions of conventioneers - prostitution is not legal in Las Vegas or Reno, the two biggest cities (by far) in the state. Nevada bans prostitution in counties with more than 700,000 residents. ${ }^{106}$ Further, even in rural counties, prostitution is permitted only in licensed brothels that adhere to strict operating requirements. ${ }^{107}$

sine the early 2000s, and with mentors in the industry going back to the 1970 s, it has been common knowledge in the adult industry that Vegas is frequently used for location shooting. 101 Joe Schoenmann, ACTION! New Los Angeles Ordinance Likely to Drive More Porn Industry Producers to Las Vegas, L.V. Sun (Mar. 6, 2012, 2:00 AM), http://lasvegas sun.com/news/2012/mar/06/1-ordinance-likely-drive-more-porn-producers-las- $\mathrm{v} /$ [https://per ma.cc/W25B-8N5H].

102 Id.

${ }^{103}$ Id.; see also Randazza, supra note 12; Porn Production Moves to Vegas After Condom Law, USA TOdAy (Jan. 17, 2014, 12:11 PM) [hereinafter Porn Production Moves], http://www.usatoday.com/story/news/nation/2014/01/17/porn-production-vegas/4557957 [https://perma.cc/DN82-3DR6].

104 Porn Production Moves, supra note 104.

105 Clark County, Nev., Code $\$ 30.44-1$ (2014).

106 Nev. Rev. STAT. \$ 244.345 (2016).

107 See, e.g., id. $\S 244.345,201.380,201.390$. 
Certainly, in the event that a porn company wanted to film in Nevada, it could set up in Pahrump, after opening its own brothel-but given the myriad of brothel-specific regulations that need to be followed, this would be wildly impractical. Further, if Nevada were to implicitly adopt Freeman, the state could not require adult film production to take place only in brothels. ${ }^{108}$

To make it even more clear that there would be no need to do so, the $\mathrm{Ne}$ vada prostitution statute historically contained the same gratification requirements as California and New Hampshire. ${ }^{109}$ The statute defines a "prostitute" as a person who engages in sex with another person, for a fee, for the purpose of arousing or gratifying the sexual desire of either person. ${ }^{110}$ Accordingly, unless the English language has markedly different definitions in New Hampshire and California than it has in Nevada, it would seem that Nevada's courts would be compelled to come to the same statutory construction analysis as their counterparts - that is, if a porn production ever came under a prosecutor's eye.

But, for a brief moment, it seemed that there was a desire to challenge the Freeman language in Nevada's statute, with the potential to set off a constitutional showdown. In 2013, the Nevada assembly proposed a human-trafficking bill, $\mathrm{AB} 67 .{ }^{111}$ In the lengthy bill, there was a clever attempt to remove the "gratification" requirement from the prostitution statute, thus, opening the door (at least statutorily) to claims that Freeman did not apply in Nevada. ${ }^{112}$ Under the bill, the definition changed to a person who "for a fee, monetary consideration or other thing of value engages in sexual intercourse." ${ }^{113}$ A later committee meeting on the bill made clear that, "nothing in the bill was intended to criminalize First Amendment-protected activity such as films, speech, or consenting

\footnotetext{
108 While there is little First Amendment jurisprudence in Nevada Supreme Court decisions, a recent case gives us insight into whether burdening porn producers with the requirement of only shooting in brothels instead of in studios would be met with approval. See Busefink $v$. State, 286 P.3d 599, 602 (Nev. 2012) ("[T] he Free Speech Clause prohibits the State from significantly burdening potential speakers with financial disincentives to speak ...."). A brothel studio requirement would certainly run afoul of this logic.

109 As an example, Oregon has a gratification requirement as well. See Or. REv. STAT. $\$ 167.002$ (2016) (" 'Sexual contact' means any touching of the sexual organs or other intimate parts. . for the purpose of arousing or gratifying the sexual desire of either party."). Others do not. See Fla. STAT. § 796.07 (2016) ("any indecent or obscene act"); ARIZ. REv. STAT. ANN. § 13-3211 (2010) (“' 'Sexual conduct' means sexual contact, sexual intercourse, oral sexual contact or sadomasochistic abuse.”); Tex. PenAl CODE $§ 43.01$ (2015) (“ "Sexual conduct' includes deviate sexual intercourse, sexual contact, and sexual intercourse.”).

${ }^{110}$ NEV. ReV. STAT. $\$ 201.295$ (2016).

111 A.B. 67, 2013 Leg., 77th Sess. (Nev. 2013), https://www.leg.state.nv.us/Sessi on/77th2013/Bills/AB/AB67_EN.pdf [https://perma.cc/KV M4-4GZX] ("Sections ... of this bill amend various provisions relating to the crimes of pandering, involuntary servitude and trafficking in persons.”).

${ }^{112} I d$.

${ }^{113} I d$. Emphasis omitted.
} 
adult actors engaging in sexual conduct." ${ }^{114}$ Immediately thereafter, Assembly Amendment 793 extinguished the change, leaving the prostitution language in its original form. ${ }^{15}$ Accordingly, not only does the Nevada prostitution statute not presently encompass adult film production, but the legislative intent was to protect it as expressive activity. ${ }^{116}$

Of course, given the Freeman First Amendment analysis, such legislative intent may not matter. Even if AB 67 had changed Nevada's prostitution statute to encompass adult film production, it is unlikely that the Nevada Courts could have disagreed with the Freeman Court's First Amendment analysis. ${ }^{117}$ Given Freeman, and the AB 67 legislative history, a claim that you cannot shoot porn in Nevada would not be credible. Considering the specific zoning for adult film production facilities in Clark County, political warmth toward the industry, and a general libertarian attitude in Nevada, ${ }^{118}$ this should dispel any claims that filming porn in Nevada is either illegal or inadvisable.

\section{B. New York-Fugghedaboudit-You Can Make It Here}

In the 1970s, one New York trial court's decision supported the "porn equals prostitution" conclusion. However, it never gained traction, and to the extent it had any credit at all, it was well discredited by 2005 .

\section{People v. Kovner-Porn is Prostitution}

New York's pre-Freeman decision, People v. Kovner,${ }^{119}$ if considered in isolation, could provide a chilly welcome to the adult film industry. Still, a later decision, People v. Paulino, ${ }^{120}$ discredits any notion that Kovner is controlling or persuasive. In fact, the People v. Paulino opinion walks into a bar, locks the door, beats the living daylights out of Kovner, and dumps its body on the side of the Merritt Parkway. ${ }^{121}$

${ }^{114}$ Hearing on A.B. 67 Before the Assemb. Ways \& Means Comm., 2013 Leg., 77th Sess. 7 (Nev. 2013) [hereinafter Assembly Hearing on A.B. 67]; see also Hearing on A.B. 67 Before the S. Comm. on the Judiciary, 2013 Leg., 77th Sess. 8 (Nev. 2013) [hereinafter Senate Hearing on A.B. 67].

115 Nev. A.B. 67.

${ }^{116}$ Assembly Hearing on A.B. 67, supra note 115, at 7; see also Senate Hearing on A.B. 67, supra note 115 , at 8 .

${ }_{117}$ See, e.g., Silvar v. Eighth Jud. Dist. Ct., 129 P.3d 682 (Nev. 2006) (finding a prostitution loitering ordinance overbroad under the First Amendment); Julian v. Las Vegas, 493 P.2d 1037 (Nev. 1972) (adult businesses entitled to obscenity hearing before seizure by officials).

118 See Nevada, MERCATUS CENTER, http://www.freedominthe50states.org/overall/nevada [https://perma.cc/WY2C-HSDB] (noting that "Nevada has a reputation as a libertarian state, mostly because of legal prostitution and gambling ....") (last visited Sept. 13, 2016).

${ }_{119}$ People v. Kovner, 409 N.Y.S.2d 349 (N.Y. 1978).

${ }^{120}$ People v. Paulino, No. 6687/04, 2005 N.Y. Misc. LEXIS 3430 (N.Y. Sup. Ct. Aug. 4, 2005).

${ }^{121}$ See Goodfellas (Warner Bros. 1990). 
To understand Kovner and Paulino, we must return to California, to a time before Freeman. Before Freeman, California had People v. Fixler. ${ }^{122}$ In Fixler, the defendants were, like Freeman, shooting pornography ${ }^{123}$ and, also like Freeman, were convicted of pandering. ${ }^{124}$ But there was a key distinction: the actor in their works was fourteen years old. ${ }^{125}$ The Fixler Court held that even if the Defendants "intended to use the photographs in a nonobscene publication, the fact remains that in order to obtain these photographs they become, by definition, common panderers and were not immune from prosecution of their crimes." 126

The California Appellate Court rejected Fixler's First Amendment defense because the underlying crime, lewd conduct with a minor, was independent of the creation of First Amendment protected materials. This distinction aside, Freeman explicitly rejected Fixler's logic that merely paying (adult) actors to be in a porn movie could be deemed unlawful when the payment was intended for acting services, but not for personal sexual gratification. ${ }^{127}$

So why do I fixate on Fixler at this point? Because the only New York case on point in this discussion is People v. Kovner. ${ }^{128}$ In that case, a New York trial court relied on Fixler and found that the prostitution statute could indeed be used to prosecute pornography. New York State Supreme Court Justice Robert M. Haft appeared to be quite delighted with the idea. ${ }^{129}$

The People's theory of the "promoting prostitution" charges is quite novel that a person may be guilty of promoting prostitution if he "advances or profits" from the conduct of "actors and actresses" who engage in explicit sexual conduct as paid performers. This is the first time in this jurisdiction that the prostitution statute has been utilized in an effort to curb pornography. ${ }^{130}$

Although Kovner raised the same First Amendment arguments in his defense as did Mr. Freeman, Justice Haft explicitly rejected them. Justice Haft did not seem to appreciate that the Fixler prosecution was based on lewd conduct with a minor; instead, relying on Fixler, he made a broad pronouncement that there was a distinction between production and distribution of First Amendment protected materials. ${ }^{131}$

\footnotetext{
${ }^{122}$ People v. Fixler, 128 Cal. Rptr. 363 (Cal. Dist. Ct. App. 1976).

${ }^{123} I d$. at 364 .

${ }^{124}$ Id.

125 Id. at 365 .

${ }^{126} \mathrm{Id}$. at 366.

127 See supra Part II.

${ }_{128}$ People v. Kovner, 409 N.Y.S.2d 349 (N.Y. 1978).

129 Id. at 350.

${ }^{130} I d$. (citations omitted).

${ }^{131}$ Id. at 351-52.
} 
Justice Haft noted that he was not "unmindful" of the fact that a "literal interpretation of the prostitution laws" could chill First Amendment rights. ${ }^{132}$ Nevertheless, to Justice Haft, the price was worth the reward. "[W] hen a state undertakes to regulate a social evil such as prostitution or pornography, it has a greater power to regulate the non-verbal physical conduct which may occur than to suppress depictions or descriptions of the same."133

\section{New York Post-Kovner-People v. Paulino}

Kovner was only a trial court decision, and Mr. Kovner does not appear to have sought an appeal. Nevertheless, from 1978 forward, New York prosecutors could have prosecuted pornographers with at least a trial court decision on their side. Without Freeman, there was no impediment to doing so. However, there is no record of them having done so.

Fast forward to 2005 when Jenny Paulino was prosecuted for running an escort service, which was actually a front for a prostitution operation. ${ }^{134}$ Paulino argued that the state was involved in "selective prosecution" for pursuing her, "while ignoring "Goliath corporations", that "conspicuously reap huge profits from the distribution of adult films." 135 Paulino's point was that prosecuting a little escort agency, while leaving porn producers alone, was unequal treatment.

Justice Emily Goodman was having none of it:

The defendant's entire motion hinges on a single, stale, faulty, and nonprecedential decision. The defendant cites People v. Kovner for the proposition that a film-maker, who pays actors and actresses to engage in sexual conduct for "pictorial recordation." [sic] is as guilty of promoting prostitution as are his participants. Kovner concluded that "no legal distinction" existed between a man who paid for sexual activity to be performed on him and a non-participating third party who paid for an actor to participate in sexual activity, because both involved the essential elements of prostitution: sexual activity in exchange for a fee. ${ }^{136}$

Goodman was not content to leave it at "single, stale, and faulty." She continued by questioning why, in the face of Kovner, there had not been a "torrent of prosecution against media companies for paying actors to star in pornographic motion pictures." 137 Goodman had an answer to her own rhetorical question: "This flood never materialized because Kovner's definition of prosti-

${ }^{132} I d$. at 352.

${ }^{133} I d$.

${ }^{134}$ People v. Paulino, No. 6687/04, 2005 N.Y. Misc. LEXIS 3430, at*1 (N.Y. Sup. Ct. Aug. 4, 2005).

${ }^{135} I d$. at $* 5-7$.

${ }^{136} I d$. at $* 8$ (citations omitted).

${ }^{137}$ Id. at $* 9$. 
tution is as novel as it is unjustifiably broad." ${ }^{, 138}$ She then described how the traditional notion of prostitution is a bilateral arrangement-A pays B for sexual activity to be performed on $\mathrm{A}^{139}$ She then ridiculed the Kovner decision for enlarging the scope of the crime to prohibit $\mathrm{C}$, from paying $\mathrm{B}$ for sexual activity to be performed on $\mathrm{A} .{ }^{140}$

Given that this was all dicta anyway, Goodman could have left it at that. Kovner was already an ignored derelict on the sea of jurisprudence, and Justice Goodman must have known that the case that provided Kovner's very spine, Fixler, had been done away with in Freeman. ${ }^{141}$ Nevertheless, without citing Freeman once, Goodman wrote her own First Amendment treatment of the "porn is prostitution" theory. She made it clear that Ms. Paulino's escort service could be prosecuted without fear of offending the First Amendment. Meanwhile, prosecuting adult film companies "poses thorny First Amendment issues, which do not arise in prosecuting brothels." ${ }^{142}$ She further recognized that the state would bear a heavy constitutional burden if it prosecuted an adult film producer who is "shielded by the First Amendment." 143 She contrasted this with "prosecuting a brothel with no such constitutional armor."

Accordingly, for a period of time in New York, one could have argued that in the absence of any other authority, Kovner green lighted adult film prosecutions in the Empire State. But, as Justice Goodman pointed out, none materialized. ${ }^{145}$ Once Freeman wiped Fixler off the map, the last of Kovner's remote underpinnings collapsed, rendering it, as Goodman said, "single, stale, [and] faulty." 146

\section{Arizona-Live Sex Shows are a "No-No", but Freeman is a "Go-Go"}

In 2012, Maricopa County Attorney Bill Montgomery told the press that under Arizona law, being paid to be in a porn movie could constitute prostitution, and that Arizona law precludes the establishment of an Arizona porn industry. ${ }^{147}$ Maricopa County is no stranger to conservative law enforcement

${ }^{138} I d$.

139 Id. at $* 8$.

${ }^{140}$ Id. at $* 8-9$.

${ }^{141}$ Presumably, Justice Goodman was familiar with Freeman's existence as it was the leading case on the issue. One would have to consciously avoid it in order to be unaware of it.

142 Paulino, 2005 N.Y. Misc. LEXIS 3430 at $* 12$.

${ }^{143} I d$. at $* 13$.

${ }^{144} I d$.

${ }^{145} I d$. at $* 8-9$.

${ }^{146} I d$. at $* 8$.

${ }^{147}$ Press Release, Maricopa Cty. Att'y's Office, Cty. Att'y Comments on Possible Move of Cal. Pornographic Film Prod. to Ariz. (Mar. 13, 2012), http://www.maricopacountyattor ney.org/newsroom/news-releases/2012/2012-03-13-County-Attorney-Comments-on-Moveof-Pornographic-Film-Production-to-Arizona.html [https://perma.cc/HS9U-U3X8]; Matthew Hendley, Bill Montgomery's Warning to the Porn Industry: Filming Nudie Flicks in Arizona 
making such broad pronouncements, but was Montgomery correct? Not likely, but he at least has a shred of credibility.

Arizona does have a much broader definition of prostitution than California, and thus, adult film production arguably fits the statute. ${ }^{148}$ There is a dearth of case law providing any instruction, but there is an appellate case in Arizona examining Freeman. ${ }^{149}$ This case, State v. Taylor, suggests (without explicitly saying so) that porn producers can roll film from Winslow to Bisbee and everywhere in between.

\section{Statutorily, Porn is Probably Prostitution in Arizona}

Arizona's prostitution statutes are more conduct-restrictive than those in California, New Hampshire, and Nevada, which could support Montgomery's statement. Arizona defines prostitution as "engaging in or agreeing or offering to engage in sexual conduct under a fee arrangement with any person for money or any other valuable consideration." ${ }^{150}$ Furthermore, a prostitution enterprise is defined as "any corporation, partnership, association or other legal entity or any group of individuals associated in fact although not a legal entity engaged in providing prostitution services." 151 Both definitions seem to cover pornography production. Moreover, under Arizona law, "prostitution" and "lewdness" are separate terms. For instance, “ '[h]ouse of prostitution' means any building, structure or place that is used for the purpose of prostitution or lewdness or where acts of prostitution occur." 152 Lewd also appears in the definition of "sexual activity" but not "sexual conduct" under Arizona law. ${ }^{153}$ Only "sexual conduct" is required for prostitution. ${ }^{154}$ Thus, it is not farfetched to think an Arizona court could conclude that an act does not have to be for purpose of "sexual arousal or gratification" to constitute prostitution. ${ }^{155}$

Accordingly, if a porn producer faced prosecution in Phoenix for prostitution, the first half of the Freeman analysis might be of little comfort. Nevertheless, it does seem that beyond the text of the prostitution statutes, we can have a pornography set with the Grand Canyon in the background.

May Be Prostitution (Even Though It's Been Happening Here for Years), PHX. New TIMES (Mar. 13, 2012, 12:19 PM), http://www.phoenixnewtimes.com/news/bill-montgomeryswarning-to-the-porn-industry-filming-nudie-flicks-in-arizona-may-be-prostitution-eventhough-its-been-happening-here-for-years-6642565 [https://perma.cc/5SPY-UA84].

148 ARIZ. Rev. StAT. AnN. § 13-3211 (2010).

149 See State v. Taylor, 808 P.2d 314 (Ariz. Ct. App. 1990).

150 ARIZ.REV. STAT. ANN. § 13-3211.

${ }^{151}$ Id.

${ }^{152} I d$. (emphasis added).

153 Compare id., with ARIz. Rev. STAT. AnN. § 13-3501 (2010).

154 ARIz.REV. STAT. ANN. § 13-3211.

155 Compare Ariz. Rev. Stat. AnN. § 13-3211, with People v. Freeman, 758 P.2d 1128 (Cal. 1988) (discussing the California statutory definition of "prostitution," "sexual conduct," and a "lewd act"). 


\section{Constitutionally, Arizona is Probably Safe for Adult Film}

Arizona's Constitution gives greater protection to free speech than the Federal Constitution. ${ }^{156}$ Article 2, Section 6 of the Arizona State Constitution proscribes "[e]very person may freely speak, write, and publish on all subjects, being responsible for the abuse of that right." ${ }^{, 157}$ This text grants freedom of expression to the people of Arizona, rather than acting as a restriction on government, as does the First Amendment.

Given that speech in Arizona is freer than the First Amendment requires, ${ }^{158}$ one would assume that Arizona courts would be apt to look at the second half of the Freeman decision and feel compelled to stand alongside California ${ }^{159}$ and New Hampshire, at least on constitutional principle. ${ }^{160}$

We do not need to completely speculate. In 1990, the Arizona Court of Appeals hinted that Freeman may apply in Arizona. In State v. Taylor,${ }^{161}$ a performer was convicted of prostitution for performing in a "sex show theatre."162 The shows were "semi-private," and the viewing room was about the size of a closet with a glass window. ${ }^{163}$ Customers inserted money into a slot to keep the show going and to encourage the performers to provide a more robust viewing experience for the limited audience. ${ }^{164}$

On appeal, the Court stated, "Freeman is considerably different from this case" because, in Freeman, there was no "payment for the purpose of sexual arousal or gratification." ${ }^{165}$ Apparently, the up-close and personal nature of the show in Taylor was a little too gratifying for the audience members. The Arizona Court of Appeals also seemed to cast an approving gaze toward the crea-

156 See, e.g., Mountain States Tel. Co. v. Ariz. Corp., 773 P.2d 455, 459 (Ariz. 1989).

157 ARIZ.CONST. art. II, $\S 6$.

${ }^{158}$ See, e.g., Mountain States Tel. Co., 773 P.2d at 459 ("\$ 6 may offer substantially more protection to free expression ...."); see also, Phx. Newspapers, Inc. v. Super. Ct., 418 P.2d 594, 596 (Ariz. 1966); Empress Adult Video \& Bookstore v. Tucson, 59 P.3d 814, 818 (Ariz. Ct. App. 2002); Martin v. Reinstein, 987 P.2d 779, 788 (Ariz. Ct. App. 1999).

159 The Arizona constitution is modeled after Washington's. "Article 2, section 6 of the Arizona Constitution of 1910, enacted after ours, is identical to Washington's free speech provision." State v. Coe, 679 P.2d 353, 361 (Wash. 1984). In turn, that is modeled after California's. "Const. art. 1, §5 [of the Washington Constitution] was modeled after the California provision." Id.

${ }^{160}$ Coleman v. City of Mesa, 284 P.3d 863 (Ariz. 2012) (holding that tattooing constituted protected speech); State v. Boehler, 262 P.3d 637 (Ariz. 2011) (invalidating a panhandlers statute as not being narrowly tailored); State v. Stummer, 194 P.3d 1043 (Ariz. 2008) (reversing convictions under a statute requiring adult bookstores to close between the hours of 1:00 a.m. and 8:00 a.m.); State v. Western, 812 P.2d 987 (Ariz. 1991) (invalidating several ordinances banning stripteases for vagueness).

${ }^{161}$ State v. Taylor, 808 P.2d 314 (Ariz. Ct. App. 1990).

162 Id. at 315.

163 Id. at 315,318 .

164 Id. at 315.

165 Id. at 317 . 
tion of adult films in Arizona by making the key distinction that there was no such medium in the live sex acts at issue. ${ }^{166}$

There was no film here as in Freeman to distance the observer temporally and physically from the performers; here the customer was temporally present, distanced only by the intervening glass. In Freeman the film was the commercial product, an inescapable subject of obscenity analysis. Here the commercial product was a live sex show in a setting that facilitated and explicitly encouraged masturbation. ${ }^{167}$

The Arizona Court of Appeals would not support a conviction by holding Freeman out as a positive example, while simultaneously disapproving of a live sex show, if it were not implicitly adopting Freeman's rationale. ${ }^{168}$

The Taylor court did not stop there. While the facts of Taylor include a close encounter under the guise of a sex show, the Arizona Court made it clear that legitimate theatrical productions featuring sex shows would have to be left alone.

There are few definitional difficulties in a law that prohibits charging the customers to have sex with the actors. Voyeurism, however, unlike participatory sex, is a common element of theatre, and eros is an element of human nature that theatrical producers, performers, and patrons are constitutionally at liberty to explore. Thus, there are obvious definitional and constitutional difficulties in a law that prohibits charging a customer to watch what might be an erotic or a sexually arousing show. ${ }^{169}$

This rationale is not only similar to Freeman, but seems to take one step beyond Freeman in saying that when live sex shows are truly theatrical productions, and not just a ruse, they would have to be allowed.

Taylor does not cleanly state outright that Arizona law specifically adopts Freeman. Nevertheless, the Court's reasoning acknowledges constitutional

${ }^{166} I d$.

167 Id. at 318 .

${ }^{168}$ Other Arizona cases support this rationale by providing different treatment for different types of sexual speech. See, e.g., State v. Bauer, 768 P.2d 175, 187 (Ariz. Ct. App. 1988) (reinstating a license for an adult bookstore where the store owner was convicted of selling obscene books). In Bauer, the court noted that the state went too far in prohibiting all adult material because "one obscene book on the premises of a bookstore does not make an entire store obscene," and the state should be wary of making such prior restraints. Id. at 183; see also Collins v. Sup. Ct., 787 P.2d 1042, 1051 (Ariz. 1986) (Feldman, J., dissenting) ("We must remember that while the Constitution does not protect obscenity, it does protect many types of speech which a majority may think objectionable. For instance, sexual conduct may be explicitly described and still fall within the constitutional protection of the first amendment.”); State v. Mutschler, 65 P.3d 469, 474 (Ariz. Ct. App. 2003) (recognizing that some nude and erotic dancing is protected under the "outer perimeters of the First Amendment" but drawing the line at "live sex act businesses."); State v. Jones, 865 P.2d 138, 143 (Ariz. Ct. App. 1993) ("The law is settled that dancing is a protected form of expression; even nude dancing enjoys some protection.").

169 Taylor, 808 P.2d at 318. 
problems that come from a failure to follow Freeman. ${ }^{170}$ The Court likely made this decision based on its own constitutional instincts and not the statutory construction itself, as Arizona's prostitution statute is more conservative than California's-covering mere sexual contact or "lewd acts between persons for money or other consideration.",171

Accordingly, any decision to prosecute an adult film producer for prostitution in Arizona would run up against the First Amendment considerations that Freeman relied upon, as well as Taylor's implicit adoption of Freeman's constitutional analysis. Arizona, in light of Taylor, obviously has a policy against extending free expression protection to pretextual live performances, but its broad constitutional treatment is also likely to hinder prosecution of legitimate adult film producers, just as it would bar prosecution of legitimate live theatrical acts involving sexual conduct. It simply makes little sense that the Arizona Court of Appeals would point to legitimate live sex productions as protected, but would hold differently if there were film involved.

\section{Oregon: Anything Goes-Even Live Sex Shows}

Oregon is well known as a speech-friendly state. ${ }^{172}$ Therefore, it is little surprise that Oregon's free speech protections are so strong that Oregon blows right past California and New Hampshire with case law that says that even upclose live sex acts are permissible.

Oregon's prostitution statute ${ }^{173}$ and constitutional free speech protections include language that is similar to many other states. ${ }^{174}$ Nevertheless, the Ore-

${ }^{170} I d$.

171 Cal. Penal Code $\$ 647$ (West 2010).

${ }^{172}$ State v. Ciancanelli, 121 P.3d 613, 619 (Or. 2005) (holding that the Oregon Constitution "precludes ... laws directed at limiting or restricting any conceivable kind of communication."). In fact, the Oregon Constitution's free expression protections are so strong that even "proximity" rules in strip clubs have been held to be unconstitutional there. See City of Nyssa v. Dufloth, 121 P.3d 639 (Or. 2005); see also Adam Rick, First Amendment, Second Fiddle? Free Speech in New Hampshire's Constitution, 7 PIERCE L. Rev. 373, 402 (2009).

${ }^{173}$ Compare OR. REV. STAT. $\$ 167.007$ (2016) (“A person commits the crime of prostitution if the person engages in, or offers or agrees to engage in, sexual conduct or sexual contact in return for a fee.”), with ARIZ. REV. STAT. AnN. § 13-3211 (2010) (“"Prostitution' means engaging in or agreeing or offering to engage in sexual conduct under a fee arrangement with any person for money or any other valuable consideration."); ARK. CODE ANN. § 5-70-102 (2011 \& Supp. 2013) ("A person commits prostitution if in return for or in expectation of a fee he or she engages in or agrees or offers to engage in sexual activity with any other person.”); CONN. PENAL CODE $§ 53 a-82$ (2015) (“A person sixteen years of age or older is guilty of prostitution when such person engages or agrees or offers to engage in sexual conduct with another person in return for a fee.").

${ }^{174}$ Compare OR. CONST. art. I, $\S 8$ ("No law shall be passed restraining the free expression of opinion, or restricting the right to speak, write, or print freely on any subject whatever; but every person shall be responsible for the abuse of this right."), with ARIZ. CONST. art. II, $\S 6$ ("Every person may freely speak, write, and publish on all subjects, being responsible for the abuse of that right."); CAL. CONST. art. II, $§ 2$ ("Every person may freely speak, write and 
gon Supreme Court has interpreted the Oregon Constitution's language as protecting more speech than the Federal Constitution. ${ }^{175}$ In fact, Oregon's Constitution arguably provides the most robust protection for free expression in the United States. ${ }^{176}$ The Oregon Supreme Court consistently reminds us that Oregon takes free expression seriously. ${ }^{177}$ In fact, Oregon's Constitution goes so far as to act as a bar to prosecutions for obscenity, under state law. ${ }^{178}$ It provides "much broader protection to adult entertainment establishments, even to the point of allowing live sex shows."

Oregon confronted its own Taylor situation in State v. Ciancanelli. ${ }^{180}$ The Oregon Court of Appeals, sitting en banc, addressed the question of whether a statute prohibiting live sex acts violated the Oregon free expression clause. There, the defendant was convicted under section 167.062 of the Oregon Revised Statute ${ }^{181}$ for operating a business that offered a "menu" of live sex performances, a for-profit service. ${ }^{182}$ The "menu" suggested that the financial exchange was for gratification, and that the "performance" was a mere pretext. ${ }^{183}$

publish his or her sentiments on all subjects, being responsible for the abuse of this right."); FLA. CONST. art. I, § 4 ("Every person may speak, write and publish sentiments on all subjects but shall be responsible for the abuse of that right."); N.Y. CONST. art. I, $\S 8$ ("Every citizen may freely speak, write and publish his or her sentiments on all subjects, being responsible for the abuse of that right ....").

${ }_{175}$ See, e.g., In re Fadeley, 802 P.2d 31, 46 (Or. 1990) ("The text of Article I, section 8, is broader [than the First Amendment of the Federal Constitution] ....") (emphasis added); Deras v. Myers, 535 P.2d 541, 549 n.17 (Or. 1975) ("The difference in the language of the Oregon and federal constitutions may also be pointed to as indicating an intention to provide a larger measure of protection to free expression under the Oregon Constitution.") (emphasis added).

176 "In [Oregon] any person can write, print, read, say, show or sell anything to a consenting adult ...." State v. Henry, 732 P.2d 9, 18 (Or. 1987). Compare this with a state like Florida where the state constitution only protects the same amount of speech as the federal constitution. See discussion infra Part IV.E.

177 See, e.g., State v. Johnson, 191 P.3d 665, 669 (Or. 2008) (“"[T]he state may not suppress all speech that offends with the club of criminal law."); Henry, 732 P.2d at 10; State v. Robertson, 649 P.2d 569, 576 (Or. 1982) (explaining the Oregon Constitution "forecloses the enactment of any law written in terms directed to the substance of any 'opinion' or any 'subject' of communication, unless the scope of the restraint is wholly confined within some historical exception.").

${ }^{178}$ Henry, 732 P.2d at 16.

${ }^{179}$ Cam I, Inc. v. Louisville/Jefferson Cty. Metro Gov't, Nos. 2005-CA-000085-MR, 2005CA-000090-MR, 2005-CA-000091-MR， 2005-CA-000092-MR， 2005-CA-000100-MR, 2005-CA-000113-MR, 2005-CA-000176-MR, 2007 Ky. App. LEXIS 370 (Ky. Ct. App. Oct. 5, 2007).

${ }^{180}$ State v. Ciancanelli, 45 P.3d 451, 452 (Or. Ct. App. 2002).

181 OR. REv. STAT. \$ 167.062(3) (2016) ("It is unlawful for any person to knowingly direct, manage, finance or present a live public show in which the participants engage in ... sexual conduct.").

${ }^{182}$ State v. Ciancanelli, 121 P.3d 613, 615 (Or. 2005).

${ }^{183}$ Ciancanelli, 45 P.3d at 476. 
This is the very type of scenario that the Arizona Court of Appeals disapproved of in Taylor.

The Oregon Constitution, robust as it is, permits certain prohibitions on expression if there is a well-established, historical basis for the otherwise protected content. ${ }^{184}$ The Court of Appeals reviewed the conduct under this test (known as the Robertson test) to determine if there was a well-established, historical restriction on public sexual acts and, if so, whether that restriction encompassed the entire statute. ${ }^{185}$

After a lengthy analysis of the history of public nudity laws in the United States tracing back to early colonial times, the Court concluded that the statute fell under a long-held, historic "authority to regulate public sexual conduct." 186 Furthermore, "[t]here [was] no argument that defendant's conduct did not amount to promoting prostitution." 187

In scathing separate dissenting opinions, Judges Brewer ${ }^{188}$ and Armstrong argued that the majority ignored Oregon Supreme Court precedent. ${ }^{189}$ Both dissents relied heavily on State v. Henry, where an adult bookstore owner was convicted under section 167.087 of the Oregon Revised Statute for disseminating obscene material. ${ }^{190}$ In Henry, the Court found "that characterizing expression as 'obscenity' under any definition ... does not deprive it of protection under the Oregon Constitution." 191 Armstrong went on to say, "[a]lthough people generally can be held liable for criminal acts committed while engaged in expressive activity, some criminal laws cannot constitutionally be applied to people engaged in expressive activity," including live sexual performances. ${ }^{192}$ Furthermore, Robertson requires a history of crimes that address "tangible harm," like fraud. ${ }^{193}$ "[S] exual content of shows presented to an audience of willing adult viewers" is not one of those tangible harms. ${ }^{194}$ According to Judge Armstrong's dissent in particular, the Ciancanelli majority should only have looked at laws that restricted expression and questioned whether those laws were meant to survive adoption of the free speech provision of the Oregon Constitution. ${ }^{195}$

${ }^{184}$ See State v. Robertson, 649 P.2d 569, 576 (Or. 1982).

185 Ciancanelli, 45 P.3d at 452-53.

${ }^{186} I d$. at $458,466$.

${ }^{187} \mathrm{Id}$. at 466

188 Judge Brewer was joined by Judge Wollheim. Id. at 467, 476.

${ }^{189}$ Id. at 476. The Henry court reviewed the history of obscenity and found speech exceptions to apply only in certain circumstances and there was no historical ban on obscenity generally. State v. Henry, 732 P.2d 9, 16 (Or. 1987).

${ }^{190}$ Ciancanelli, 45 P.3d at $467-80$.

${ }^{191}$ Henry, 732 P.2d at 17.

${ }_{192}$ Ciancanelli, 45 P.3d at 477 (Armstrong, J., dissenting).

193 Id. at 479.

194 Id.

195 Id. at 480 . 
On direct review, the Oregon Supreme Court overturned the majority opinion. Although the Court adopted part of Judge Armstrong's reasoning, it went even further, concluding that Article I, Section 8 of the Oregon Constitution "precludes any restraint on most forms of expression as well as laws directed at limiting or restricting any conceivable kind of communication." ${ }^{196}$ In other words, the Oregon Supreme Court roundly rejected any form of prior restraint "whatever," 197 including restrictions on the expressive aspect of live sex shows. ${ }^{198}$

Shortly after Ciancanelli, the Oregon Supreme Court developed that jurisprudence further in the case of City of Nyssa v. Dufloth. ${ }^{199}$ In particular, the Court developed what "expression" meant under the Oregon Constitution. ${ }^{200}$ The City of Nyssa passed an ordinance that required strip clubs to impose a "four foot rule," keeping patrons at least that far away from nude dancers, at all times. ${ }^{201}$ Defendants were arrested based on a complaint that a dancer was "shaking her hair in a patron's face." 202 The Appeals Court relied on its own opinion in Ciancanelli to find that nude dancing was not protected expression under the state constitution, and of course was reversed on review. ${ }^{203}$

The Oregon Constitution "protection extends to the kinds of expression that a majority of citizens in many communities would dislike-profanity, blasphemy, pornography - and even to physical acts, such as nude dancing or other explicit sexual conduct, that have an expressive component." ${ }^{204}$ The Court went further to reject the Ciancanelli proposition that there is a historical exception "for laws regulating live public shows involving displays of nudity and sexuality." ${ }^{205}$ The "four foot rule" ordinance "appli[ed] only to one disfavored type of communication (nude performance) in one disfavored type of establishment" and thus, was "indistinguishable from ... Ciancanelli" and directed improperly at free expression. ${ }^{206}$

196 State v. Ciancanelli, 121 P.3d 613, 619 (Or. 2005).

197 Article I, section 8 of the Oregon Constitution states: "No law shall be passed restraining the free expression of opinion, or restricting the right to speak, write, or print freely on any subject whatever ...." Although section 8 seems to track the language of the First Amendment in part, one of its distinctive features is the word "whatever." That intensifying language is absent from the First Amendment, suggesting section 8 provides protective force beyond that federal counterpart. OR. CONST. art. I, $\S 8$.

198 Ciancanelli, 121 P.3d at 635.

${ }^{199}$ City of Nyssa v. Dufloth, 121 P.3d 639 (Or. 2005).

${ }^{200} I d$. at $640-41$.

${ }^{201} I d$. at 639.

${ }^{202} I d$. at 640

${ }^{203}$ City of Nyssa v. Dufloth, 57 P.3d 161, 163 (Or. Ct. App. 2002), rev'd, 121 P.3d 639 (Or. 2005).

${ }^{204}$ City of Nyssa, 121 P.3d at 642 (citing State v. Ciancanelli, 121 P.3d 613, 629 (Or. 2005)).

${ }^{205} I d$. at 643.

${ }^{206} I d$. 
With increased protection for speech in Oregon case law, the adult film industry would likely be welcomed there. Oregon brings one more question to the table: "If pornography is not prostitution, where do we draw the line?" Oregon is sui generis in that its Constitution has been interpreted to mandate that audience-driven live sex shows and obscenity are protected speech. Most other states, though likely to uphold the Freeman standard, make a point to distinguish adult film production-or even amateur film production like in Theriault-from live sex shows.

\section{E. Florida-Sunny or Dark?}

Certain parts of Florida "have been a long-time home to some of the [porn] industry's largest content producers."207 One example, Florida Beach Guy Enterprises, has produced adult films in St. Augustine since $1994{ }^{208}$ Moreover, the internationally beloved "Bang Bros" are headquartered in Miami Beach. ${ }^{209}$ The Tampa Bay and Orlando areas are also home to other well-known porn companies. ${ }^{210}$

But is all of this porn production just one prosecutorial hurricane away from being swept away? No sane person would call Florida a speech friendly state. Florida's Supreme Court has consistently reminded us that the Florida Constitution provides no greater protection to free speech than the Federal Constitution. $^{211}$ Some Florida counties routinely bring obscenity cases against

207 Walters, supra note 11.

${ }^{208}$ Porn Nearby, Fla. Times-Union (Dec. 2, 2007), http://jacksonville.com/tu-online/sto ries/120207/lif_221825643.shtml\#.V13V-1dWa0h [https://perma.cc/R3FD-EY8W].

${ }^{209}$ In the interest of full disclosure, the Author proudly represents Bang Bros.

${ }^{210}$ See, e.g., Biography: It's Time You Knew a Bit More About Me-My Real Name is Diana Tho Many Still Call Me Desi, PoRn IN THE VAlley (Jan. 20, 2012), http://pornintheval ley.com/2012/01/20/biography-its-time-you-knew-a-bit-more-about-me-my-real-name-is-

diana-tho-many-still-call-me-desi/ [https://perma.cc/9G6X-M3FF]. In fact, the Tampa Bay area is so tolerant of the industry that it has yet to crack down on even the most shocking porn production, including an adult mother-daughter team. See David Moye, MotherDaughter Porn Duo Jessica Sexxxton, Monica Sexxton Aiming to Be Filthy Rich, HuFFINGTON POST (Dec. 5, 2012, 6:04 PM), http://www.huffingtonpost.com/2012/12/06/ mother-daughter-porn-duo-jessica-monica-sexxxton_n_2238052.html [https://perma.cc/M4E V-V6GR].

${ }^{211}$ See, e.g., Daytona Beach v. Del Percio, 476 So. 2d 197, 203 (Fla. 1985) ("We do not find any greater protection under the Florida Constitution."); Miami Herald Publ'g Co. v. Ane, 423 So. 2d 376, 385 (Fla. Dist. Ct. App. 1982) ("Nor can the decision here be revived, as urged, as an interpretation of the Florida Constitution according greater constitutional protection for defamation defendants than that afforded by the First Amendment . ... ."); Fla. Canners Ass'n v. Fla., Dep't of Citrus, 371 So. 2d 503, 517 (Fla. Dist. Ct. App. 1979) ("Under the circumstances, and in the absence of any expression by our supreme court that the Florida guarantee [for freedom of speech] is broader in scope than the federal, we conclude that the two are the same and will not treat them separately."). 
pornographers. ${ }^{212}$ And, there was at least one case in which a Florida prosecutor seemed primed to give a run at challenging the Freeman analysis in Florida. ${ }^{213}$ Nevertheless, Florida is a patchwork of conservative and liberal elements - with Tampa and Miami standing alongside parts of Florida where time seems to have stood still.

\section{Polk County}

It is safe to say that if anyone would try a Freeman prosecution in Florida, it would be Polk County Sherriff, Grady Judd. Sherriff Judd is well known as a moral crusader and is as anti-porn as they come. ${ }^{214}$ Judd prosecuted website operator Chris Wilson when Wilson's website came under the spotlight for allowing military members to post photos of Iraqi war dead that showed misconduct by American soldiers. ${ }^{215}$ Judd charged Wilson with 300 counts of obscenity due to the hundreds of sexually explicit photos on his website-very few of which were more than garden-variety nudity. ${ }^{216}$

Another infamous Polk County case took place in 1999 where Herbert and Tammy Robinson ran an amateur porn website from their home in Polk County, Florida. In the course of publishing the site, they picked up a stalker, who threatened to rape and kill Ms. Robinson, while making her children watch. ${ }^{217}$ Understandably, the Robinsons called the FBI, who referred them to the local

${ }^{212}$ Walters, supra note 11. In Polk County, for example, dozens of cases are brought each year. Though many are dismissed, it is a sure way to discourage production of adult films. See id.

${ }^{213}$ See Lawrence G. Walters, Anatomy of an Obscenity Prosecution: The Tammy Robinson Case Study, FIRSTAMENDMENT.COM, http://www.firstamendment.com/wp-content/uploads/20 13/pdf/Anatomy\%20of\%20an\%20Obscenity\%20Prosecution.pdf [https://perma.cc/XH9H-N KKG] (last visited Sept. 27, 2016); see also discussion of Robinson infra Part IV.E.1.

${ }^{214}$ See, e.g., Michael Kruse, Polk Sheriff Grady Judd Makes His Name on Moral Outrage, TAMPA BAY Times (Feb. 4, 2011, 12:24 PM), http://www.tampabay.com/news/publicsafe ty/polk-sheriff-grady-judd-makes-his-name-on-moral-outrage/1149570 [https://perma.cc/4V GB-KWXF]; see also Jeff Gore, Church and State: Polk County Sheriff Grady Judd's Mission from God to Eliminate Obscenity Knows No Bounds, ORLANDO WEEKLY (Feb. 23, 2011), http://orlandoweekly.com/news/church-and-state-1.1109454 [https://perma.cc/WP2UXX3B].

${ }^{215}$ David Kushner, Casualty of Porn: Is Chris Wilson Facing Jail Over Amateur Smut or Dead Iraqis, ROLLING STONE (Dec. 5, 2005), http://www.firstamendment.com/wpcontent/uploads/2013/pdf/Rolling_Stone_11.28.05.pdf [https://perma.cc/993W-QS2A]; Jonathan Turley, Chris Wilson's War: Publisher of Iraqi War Dead Arrested and Computer Seized: Was it Porn or Politics?, JonathanTurley.org (Jan. 6, 2008), http://jonathantur ley.org/2008/01/06/chris-wilsons-war-publisher-of-iraqi-war-dead-arrested-and-computerseized-was-it-porn-or-politics [https://perma.cc/MF9Z-SUM2].

216 JefF Sparrow, Killing: Misadventures in Violence 2-3 (2009); Dana Willhoit, War, Porn Web Site Creator Arrested, LEDGER (Oct. 8, 2005, 8:53 AM), http://www.theledg er.com/article/20051008/NEWS/510080427?p=3\&tc=pg [https://perma.cc/UW7H-6CDP].

217 John InCE, The Politics of Lust 194 (Prometheus Books 2005) (2003). 
"Computer Crimes Unit" in Polk County. ${ }^{218}$ Upon opening the investigation, the focus immediately shifted away from the death threats into an obscenity prosecution against the victims. ${ }^{219}$ Judd even kicked off the festivities with a SWAT Team raid. ${ }^{220}$

In an act of unethical prosecutorial creativity, Judd pushed the Florida Department of Children and Families to remove the Robinson children from the home. ${ }^{221}$ Ultimately, the case was dropped, and Robinson sued the Polk County authorities. ${ }^{222}$ Despite his willingness to stoop to such levels as seizing a pornproducer's children, Grady Judd never went so far as to charge the Robinsons with prostitution. ${ }^{223}$ Over the years, Judd has brought his fair share of obscenity charges, ${ }^{224}$ but he has never once tried to do a Freeman-style prosecution. ${ }^{225}$ Given his clear zeal to punish pornographers, one would think that if Florida law could support it, he would have charged them with such a crime, or at the very least, used it to extract a more favorable plea deal.

\section{Outside Polk}

There have been relatively few other pornography prosecutions outside of Polk County. One did occur in 2008 when prosecutors in the Florida Panhandle charged porn producer Clinton McCowan, a.k.a. "Ray Guhn," with obscenity and prostitution in connection with his running of an adult film company. ${ }^{226}$ The prostitution charges were never fully explained, though, and were ultimately settled out of court. ${ }^{227}$

218 Walters, supra note 214 , at 1.

${ }^{219} I d$. at 3.

${ }^{220} I d$. at 4.

${ }^{221} I d$.

222 Vickie Chachere, Internet Porn Case Dropped Against Couple, LubBock Avalanche-J. (Feb. 7, 2001), http://lubbockonline.com/stories/020701/upd_075-7363.shtml\#.V132W1dWa $0 \mathrm{~g}$ [https://perma.cc/TY6G-59LJ].

${ }^{223}$ Walters, supra note 214 , at 4.

${ }^{224}$ See, e.g., Suzie Schottelkotte, Former Lake Wales Couple Plead No Contest in Pornography Case, LEDGER (Feb. 28, 2012, 11:51 PM), http://www.theledger.com/article/201202 28/NEWS/120229245 [https://perma.cc/9UCA-CF42].

${ }^{225}$ E-mail from Lawrence G. Walters, Att'y, Walters Law Group, to author (Nov. 1, 2015 , 3:37 PST) (on file with author). The Author has also interviewed attorneys in Florida who regularly represent adult film producers, including Larry Walters, Gary Edinger, Jamie Benjamin, Danny Aaronson, and Luke Lirot. The attorneys all indicated that they know of no other similar prosecutions of adult film producers in Florida. See also D. Gill Sperlein, et al., Is It Legal to Shoot Porn in Your State?, XBIz (Mar. 30, 2014), http://www.xbiz.com/arti cles/177157 [https://perma.cc/DM84-BXAH].

${ }^{226}$ Anne Winter, Ray Guhn Pleads Not Guilty, XBiz (Aug. 1, 2007, 5:00 AM), http://www.xbiz.com/news/news_piece.php?id=82578 [https://perma.cc/5J58-N52F].

${ }^{227}$ Media Update-July 7, 2008, NAT'L COAL. SEXUAL Freedom, https://ncsfree dom.org/please-login-to-kap/item/302-media-update-july-7-2008.html [https://perma.cc/KS4 H-49VW] (last visited Sept. 27, 2016). 
Even law enforcement officials in conservative Florida counties acknowledge that pornography production is difficult to prosecute unless the product is obscene. ${ }^{228}$ Jacksonville Police Lieutenant Mike Gwynes commented that " $[t]$ here are so many constitutional protections, it's extremely difficult to prosecute .... It really has to go way outside society's norms to come up to the level of criminal., 229

Accordingly, despite the lack of any authority, it is relatively safe to say that if Florida were prepared to take an anti-Freeman position, it would have done so by now. Of course, the fact that it has not doesn't preclude it from doing so today. But, when even Polk County and Jacksonville are not prepared to lay out the porn production dragnet, it is reasonable to assume that the rest of the state will remain open for business.

\section{F. Missouri}

Missouri is not exactly a hotbed of porn production. Therefore, one might wonder why this study would consider it important enough for inclusion. The fact is, there is a lack of case law nationwide challenging any of Freeman's notions - but Missouri is home to the only case that calls some of Freeman's presumptions into question.

\section{Show Me Prostitution}

The current version of Missouri's prostitution statute is somewhat confusing, seeming to be a Freeman-style statute. However, the new version of the statute, which comes into effect on January 1, 2017, is tailored to exclude Freeman-style statutory analysis. ${ }^{230}$

Missouri's current prostitution statute provides somewhat circular text: "A person commits the crime of prostitution if the person performs an act of prostitution."231 A person commits prostitution when "he engages or offers or agrees to engage in sexual conduct with another person in return for something of value to be received by the person or by a third person." 232 In turn, "sexual conduct" is further defined under Missouri's statute. ${ }^{233}$ Part (a) requires only vaginal penetration, "however slight," while part (b) applies to any "deviate" intercourse, which applies to any other form of copulation. ${ }^{234}$ Meanwhile under part (c), the Missouri legislature decided to sweep up anything else, including "any touching, manual or otherwise, of the anus or genitals of one person by

228 See Walters, supra note 11.

${ }^{229}$ Porn Nearby, supra note 209.

${ }^{230}$ Mo. Rev. Stat. $\$ 567.010$ (effective Jan. 1, 2017).

${ }^{231}$ MO. REV. STAT. $\$ 567.020$ (2015).

${ }^{232}$ Id. $\$ 567.010(2)$.

${ }^{233}$ Id. \$ 567.010(4).

${ }^{234}$ Id. § 567.010(4)(a), (b). 
another, done for the purpose of arousing or gratifying sexual desire of either party. ${ }^{235}$ This language seems to be a Freeman-style statutory construction, but it offers little comfort to adult film producers if it merely exempts touching, and not intercourse of any kind.

Under the statutory text come January 1, 2017, even simulated sex on camera might be illegal. On that date, a new version of the statute will come into effect, which sweeps everything up into one very expansive definition. Under the new version, "[a] person commits the offense of prostitution if he or she engages in or offers or agrees to engage in sexual conduct with another person in return for something of value to be received by any person."236

\section{Porn Up Against Wahl}

To remove most doubt from the picture, there is a Missouri Appellate Court decision that is mostly on-point-and it seems to prohibit porn production in Missouri, at least with the same strength of authority that Taylor permits it in Arizona.

In 2002, Missouri's Appellate Court had occasion to deal with both a live sex show and, tangentially, acting for pornographic film purposes. ${ }^{237}$ The outcome was contrary to Freeman, but given the textual difference between the Missouri statute in place at the time and the California prostitution statute, the decision was not incompatible with the Freeman statutory analysis. Given the even tighter language of the 2017 Missouri prostitution statute, it would seem that unless this case is overturned, and on a constitutional basis, Missouri is a questionable place to shoot porn.

In the 2002 case, Wahl and his wife posted an ad in a local newspaper advertising that they would provide an "erotically entertaining and educational live show featuring adult performers." 238 Detectives paid the couple $\$ 200$, and they provided the undercover officers with "various books, literature and pamphlets of a sexual nature." 239 They then, in the parlance of our time, "got down to business." 240 One of the detectives requested permission to videotape the performance, and Wahl agreed. ${ }^{241}$ The detectives then issued a writ of coitus interruptus and arrested the couple, charging them with misdemeanor prostitution. ${ }^{242}$ The jury found Mr. Wahl guilty, ${ }^{243}$ and he appealed pro $s e .{ }^{244}$

${ }^{235} I d$. $\$ 567.010(4)(\mathrm{c})$ (emphasis added).

${ }^{236} I d$. $\$ 567.020$.

${ }^{237}$ State v. Wahl, 89 S.W.3d 513, 514 (Mo. Ct. App. 2002).

${ }^{238} I d$.

${ }^{239} \mathrm{Id}$.

${ }^{240} I d$. ("Defendant and co-defendant then placed their mouths on each other's genitals and performed oral sex.").

${ }^{241} I d$.

${ }^{242} I d$. 
Because Wahl represented himself in the appeal, he appears to have made a significant number of procedural errors. It is unclear whether he raised a First Amendment argument at trial, but the Court noted that he did raise it, albeit improperly, as one of his three arguments on appeal. ${ }^{245} \mathrm{He}$ also argued that his conduct did not fit the prostitution statute, and that the prosecution violated his due process rights and his right to be free from religious discrimination. ${ }^{246}$

The Appellate Court seemed to have little tolerance for Wahl, and made it clear that it was under no obligation to review the defective appeal. ${ }^{247}$ Nevertheless, the Court stated that it would review the statutory construction portion of Wahl's appeal ex gratia- or out of kindness or grace. ${ }^{248}$

Having taken Wahl's arguments as a matter of charity, the Court made short work of the statutory construction issue. Under Missouri law, as explained above, Wahl's conduct fit the prostitution statute. ${ }^{249}$ If there was any doubt, the Missouri Appellate Court made it clear. "The intent and purpose of the prostitution statute is to outlaw commercial sexual conduct including but not limited to sexual intercourse.,"250

But what of the constitutional argument? The Missouri Appellate Court's ex gratia emotions were apparently not strong enough to warrant constitutional analysis. Therefore, the Court ruled against Wahl without even considering his constitutional arguments. ${ }^{251}$

Stating that Missouri courts have ruled definitively on the issue is oversimplifying things. The Missouri court did have the constitutional issue before it, albeit improperly briefed. It presumably was aware of Freeman, and chose to avoid engaging in any constitutional analysis at all. What does this suggest? Perhaps the Court knew that it would have no choice but to rule in Wahl's favor if it addressed his First Amendment arguments, and for that reason they declined, since there was no obligation to do so. Or, perhaps the Missouri Court's silence on the constitutional issue is a result of complete contempt for the argument. Speculating on it is difficult, but porn producers should consider the fact that the weight of the law, however light it is, is against them in Missouri unless there is another case giving an opportunity for a properly briefed argument to the Missouri Court of Appeals. Of course, if there is a shoot in Mis-

${ }^{243} I d$. at $514-15$. Ms. Wahl was arrested and was also a co-defendant. Id. at 514 . The outcome of her case is not discussed in the appellate court opinion.

${ }^{244} I d$. at 514.

${ }^{245} I d$. at $515-16$.

${ }^{246} I d$. at 516 .

${ }^{247} I d$.

${ }^{248} \mathrm{Id}$.

${ }^{249} \mathrm{Id}$.

${ }^{250} \mathrm{Id}$.

${ }^{251} I d$. at $516-17$. 
souri, and a prosecutor tries to invoke Wahl, it could set up a full constitutional showdown there.

\section{THE First AMENDMENT AND THE HyPOTHETICAL CONSTITUTIONAL SHOWDOWN}

Courts that have dealt with the issue of pornography versus prostitution, including New Hampshire in Theriault and California in Freeman, based their decisions on State Constitutions. ${ }^{252}$ This has ensured that these cases are not open to review by the U.S. Supreme Court. ${ }^{253}$ In spite of that, we are not without any higher court guidance on the First Amendment issue; our guidance is just not binding authority.

Before Freeman, there was at least one reported case rejecting Freeman's future analysis, although the case provided little analysis of its own. In United States $v$. Roeder, the defendant was prosecuted under the Mann Act. ${ }^{254}$ The Mann Act prohibits the interstate transportation of any individual in order to have that person engage in prostitution. ${ }^{255}$ In Roeder, a producer of adult films was convicted when he was prosecuted for driving a woman from Missouri to Kansas to be in a porn film. ${ }^{256}$ Since Roeder hired her to engage in sexual conduct, and she was driven across state lines for that purpose, it met the definition of "prostitution." ${ }^{257}$ The Tenth Circuit then upheld the conviction. ${ }^{258}$

Unlike many other cases, Roeder himself was going to be in the movie along with the woman. ${ }^{259}$ Therefore, "he fulfilled not only the broad Supreme Court definition of prostitution, but the more basic and narrower understanding of prostitution by being the 'customer' who paid a woman to have sex with him." 260 This case not only steps outside of Freeman's analysis, but it also predates it. This seems to suggest that its holding is either no longer good law, or is limited to its facts. The Tenth Circuit side-stepped the First Amendment analysis, making it clear that Congress could prohibit "the interstate transportation of a woman for the purpose of prostitution" and that the Mann Act "is not a suppression of speech or expression." 261 Nevertheless, the opinion does not

${ }^{252}$ California v. Freeman, 488 U.S. 1311, 1315 (1989); State v. Theriault, 960 A.2d 687, 693 (N.H. 2008).

${ }^{253}$ Note that if Theriault and Freeman had come out against pornography, they would likely have had to perform a federal constitutional analysis appealable to the Supreme Court.

${ }^{254} 18$ U.S.C. \$ 2421 (2012); United States v. Roeder, 526 F.2d 736, 737 (10th Cir. 1975) cert. denied, 426 U.S. 905 (1976).

${ }^{255}$ Roeder, 526 F.2d at 739.

${ }^{256}$ Id. at 737.

${ }^{257} \mathrm{Id}$.

${ }^{258} I d$. at 739.

${ }^{259} I d$. at 737.

${ }^{260}$ Tonya R. Noldon, Note, Challenging First Amendment Protection of Adult Films with the Use of Prostitution Statutes, 3 V A. SPORTS \& ENT. L.J. 310, 315 (2004).

${ }^{261}$ Roeder, 526 F.2d at 739. 
consider that if Mr. Roeder were not acting in the film, things might have been very different-one way or the other.

Aside from Roeder and Freeman's denial of stay, there has been one other higher court opinion that has hinted at the First Amendment application to adult entertainment, even in the case of live shows. In a 2001 Seventh Circuit case, the Court upheld a city zoning ordinance denying the plaintiff's burlesque club near residential neighborhoods. ${ }^{262}$ Writing for the panel, Judge Posner opined that "there is no reasonable doubt that a burlesque theater that exhibits nude dancing is similar to an adult movie theater. Both are theaters, both present erotic entertainment, and if anything a live sex show is more erotic than a celluloid one."263 The Court hinted at problems where authorities deny expressive activity, including erotic dancing, but did not have to perform a First Amendment analysis since the case was constricted to zoning and not an outright ban. ${ }^{264}$

Before officials make any hasty decisions to move forward with prosecution of adult film producers, they should be wary of the effects of both a Freeman type decision and an appeal to a higher court requiring First Amendment analysis. When California appealed Freeman to the U.S. Supreme Court, the Court declined to accept certiorari due to Justice O'Connor's analysis that the independent and unreviewable state ground for the decision meant that a Supreme Court decision would be merely advisory in nature. ${ }^{265}$ Thus, the possibility that the Supreme Court could consider whether prostitution laws could be used to prohibit professional porn production remains open. Such a finding would be out of alignment with the prevailing trend in the law. Further, while Roeder seems to have rejected Freeman's not yet existing analysis, it did so in few words, and did so under facts that would have constituted "prostitution" even under Freeman, in that the producer of the movie was not only the producer, but also going to be sexual partners with the woman transported across state lines. ${ }^{266}$

Freeman's First Amendment analysis seems sound, with no decisions calling it into question-anywhere-since it was entered. The First Amendment provides that "Congress shall make no law ... abridging the freedom of speech.,"267 "[A]s a general matter, 'the First Amendment means that government has no power to restrict expression because of its message, its ideas, its subject matter, or its content." ",268 The Supreme Court has ruled time and again that the professional production and distribution of pornography is First

${ }^{262}$ Blue Canary Corp. v. Milwaukee, 270 F.3d 1156, 1157 (7th Cir. 2001).

${ }^{263} \mathrm{Id}$. at 1158.

${ }^{264} \mathrm{Id}$. at 1157.

${ }^{265}$ California v. Freeman, 488 U.S. 1311, 1315 (1989).

${ }^{266}$ Roeder, 526 F.2d at 737.

267 U.S.CONST. amend. I.

268 Ashcroft v. Am. Civil Liberties Union, 535 U.S. 564, 573 (2002) (citation omitted). 
Amendment protected, as long as the materials are not legally obscene. ${ }^{269}$ As such, any application of a prostitution law to prohibit the creation of a bona fide pornographic film would be " "presumptively invalid' . . . and the Government bears the burden to rebut that presumption." 270 Occasionally, the Court engages in balancing of the value in unprotected speech, but it does so categorically and not on the basis of particular content. ${ }^{271}$ Restrictions on a few historic categories of speech have passed constitutional scrutiny-obscenity, defamation, fraud, incitement, and speech integral to criminal conduct-categories that "have never been thought to raise any Constitutional problem.",272

Since the Court has categorically protected commercial pornography, time and again, ${ }^{273}$ it is not likely about to change direction to create a new category of unprotected speech of commercially produced pornography. In fact, the protection of commercial pornography is so constitutionally ingrained, that Congress saw fit to actually regulate the industry. In 1988, Congress enacted the Child Protection and Obscenity Enforcement Act. ${ }^{274}$ Section 7513(a) of the Act, known by its codified section number as $\$ 2257$ requires recording and reporting of certain age information about the professional adult film actors.

Under 18 U.S.C. $\$ 2257$, producers of films depicting "sexually explicit conduct" must maintain age and identity records for their actors. Section 2257 defines "sexually explicit conduct" as "sexual intercourse, including genitalgenital, oral-genital, anal-genital, or oral-anal, whether between persons of the same or opposite sex. ${ }^{275}$ Under the law, a producer must examine, and retain a copy of, each model's or performer's photo identification. ${ }^{276}$ It must also make these records available for government inspection. ${ }^{277}$ Further, the regulations require a statement that discloses where the records are, and the name of any

\footnotetext{
269 See Miller v. California, 413 U.S. 15, 24 (1973); see also, Fort Wayne Books, Inc. v. Indiana, 489 U.S. 46, 79 (1989) (noting the existence of a "line between protected pornographic speech and obscenity.").

${ }^{270}$ United States v. Playboy Entm't Grp., 529 U.S. 803, 817 (2000) (quoting R.A.V. v. St. Paul, 505 U.S. 377, 382 (1992)).

${ }^{271}$ See generally, John Hart Ely, Comment, Flag Desecration: A Case Study in the Roles of Categorization and Balancing in First Amendment Analysis, 88 HARV. L. REV. 1482 (1975); Geoffrey R. Stone, Restrictions of Speech Because of Its Content: The Peculiar Case of Subject-Matter Restrictions, 46 U.CHI. L. REV. 81 (1978).

${ }^{272}$ United States v. Stevens, 559 U.S. 460, 460 (2010) (citing Chaplinsky v. New Hampshire, 315 U.S. 568, 572 (1942)).

${ }^{273}$ See, e.g., Ashcroft, 535 U.S. at 564; Miller, 413 U.S. at 22 n.3; Redrup v. New York, 386 U.S. 767 (1967); Freedman v. Maryland, 380 U.S. 51, 53 (1965); A Quantity of Copies of Books v. Kansas, 378 U.S. 205, 214 (1964); Manual Enters., v. Day, 370 U.S. 478, 479 (1962).

${ }^{274}$ See Am. Library Ass'n v. Barr, 956 F.2d 1178, 1182 (D.C. Cir. 1992).

27518 U.S.C. $\$ 2256(2)(A)$ (2012).

${ }^{276}$ See id. $\$$ 2257(a)(1), 2257(b); 28 C.F.R. $\$ 75.2$ (2015).

277 See 18 U.S.C. $\$ 2257($ c); 28 C.F.R. $\$$ 75.4-75.5.
} 
custodian. ${ }^{278}$ This complex regulatory regime seems awfully in-depth and complicated if the mere act of commercial production of pornography was already illegal. It is akin to creating a complex set of regulations for the illegal distribution of MDMA in nightclubs. This seems to be at least a tacit admission that Roeder is not likely to be repeated in the true commercial pornography context.

Freeman is the only case to address the First Amendment implications of applying prostitution laws to commercial production of pornography. However, it seems that the lack of jurisprudence on that particular issue since then has been the result of a recognition even by anti-porn forces that such an impediment to the production of pornography is dead on arrival.

\section{CONCLUSION}

It is true that only two states have definitively answered the precise question of "is porn production prostitution?" But, a state need not address that precise question for it to be a settled question. The question really comes down to two questions. First, we ask whether the statute prohibits merely "sexual gratification" or whether it prohibits all "sexual contact." If the former, then an analysis under Freeman and Theriault tells us that porn production does not even implicate the statute. If the statute prohibits "sexual contact" or is even broader in scope, then we must ask whether the state and Federal Constitution would tolerate prosecution on this basis. Thus far, it seems unthinkable that such a prosecution would pass muster under either the Federal Constitution or any state counterparts.

In the event that another state wishes to tackle this issue, it would likely be a fool's errand. Only a fanatical anti-porn crusader would bring such a prosecution at this point. And if such a prosecutor brought such a case, the most likely outcome would be a state court decision following Freeman or a landmark decision based on the Federal Constitution.

Ironically the reasoning that gives life to the myth that filming pornography is legal only in California and New Hampshire is the same mythological spirit preventing many states from confronting Freeman.

No prosecutor wants to be responsible for bringing the landmark case resulting in their state becoming the latest safe-haven for adult content production. A state attorney who lets that happen on his (or her) watch can kiss any political or judicial aspirations "goodbye." Therefore, a quiet detent has existed in the other forty-eight states (including Florida), where the applicability of prostitution laws to adult content production remains unsettled, with law enforcement generally looking the other way when it comes to such issues. ${ }^{279}$

Even if a state court were able to hypothetically put an end to Freeman's shadow once and for all, would it be worth it? What are the stakes? If success-

${ }^{278}$ See 18 U.S.C. $\S 2257($ e); 28 C.F.R. § 75.6.

279 Walters, supra note 11. 
ful, would it really put an end to porn production, or would it just go underground? It may be true that the number of filed permits for adult film studios dropped dramatically in Los Angeles since the institution of the "condom law," but still, this doesn't mean that porn is not being produced within the city limits. Though many producers have moved to different cities and counties within California, and others to neighboring states, some have chosen to ignore the ordinance all together. ${ }^{280}$

In light of "real" crime, should law enforcement really look at porn film production as a priority? A successful prosecution seems constitutionally unlikely, and a single prosecution would likely have no definitive, actual effect upon production in that state. Meanwhile, any state with a definitive Freemanlike ruling would be added to the list of states where there is an absolute, definitive decision rendering the entire state a zone for protected porn production. At the end of the day, commercial pornography is not prostitution in most states. Even in the states where it could be, the First Amendment or the State Constitution's freedom of expression clause will step in and block any effort to prosecute it as such-no matter how hard politicians, anti-porn zealots, or a misinformed media may cling to the urban legend that porn can only be shot in California and New Hampshire.

280 See Susan Abram, Condom Bill Dies in Key California Committee, Porn Industry Satisfied-for Now, L.A. DAILY NEws (Aug. 14, 2014, 8:07 PM), http://www dailynews.com/gov ernment-and-politics/20140814/condom-bill-dies-in-key-california-committee-porn-industry -satisfied-x2014-for-now [https://perma.cc/72US-ZFCG]; Editorial, Condoms for Porn Actors: A Statewide Law Isn't the Answer, L.A. Times (Aug. 10, 2014, 5:00 AM), http://www.latimes.com/opinion/editorials/la-ed-condoms-porn-20140810-story.html [https://perma.cc/Z7A7-2LAW]; John Rogers, LA Porn Producers Go Underground After Condom Law, BAKERSFIELD NOw (Aug. 6, 2014), http://www.bakersfield now.com/ news/local/LA-porn-producers-go-underground-after-condom-law-11-17-2015 [htt ps://perm a.cc/DGL5-GRN3]; US Court Upholds Los Angeles Condom Law for Porn Actors, BBC News (Dec. 16, 2014), http://www.bbc.com/news/world-us-canada-30489942 [https:// perm a.cc/MX27-6DDN]. 
